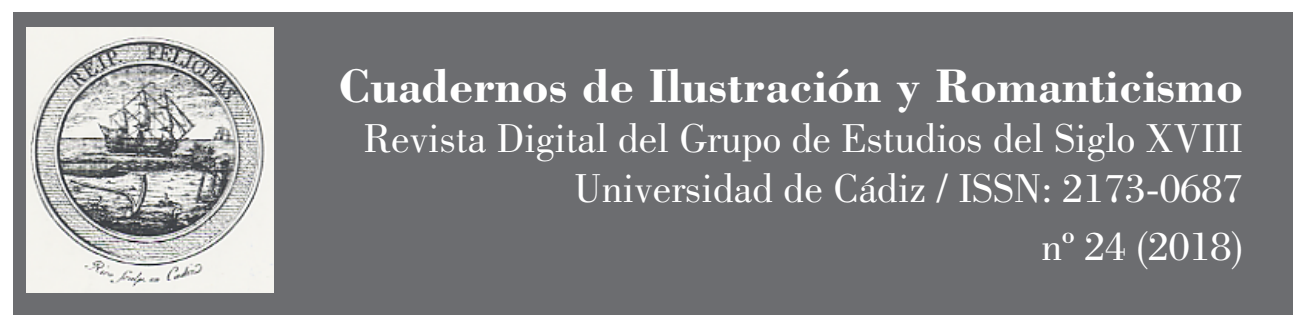

\title{
UN «EDITOR INFATIGABLE»: LA TRAYECTORIA BIOGRÁFICA, EDITORIAL Y EMPRESARIAL DE IGNACIO BOIX
}

\author{
Ana Peñas Ruiz \\ (Universidad a Distancia de Madrid) \\ Recibido: 27-3-2018 / Revisado: 19-6-2018 \\ Aceptado: 19-6-2018 / Publicado: 20-12-2018
}

RESUMEN: Ignacio Boix y Blay fue un librero,impresory editorque desplegó unaintensaactividad durante el segundo tercio del siglo XIX, fundamentalmente en Madrid, pero también en otros puntos estratégicos de la península, Europa y Ultramar. Exponente paradigmático del mercado editorial y tipográfico español moderno en una etapa de transición entre las antiguas prácticas gremiales del Antiguo Régimen y la conformación del nuevo mercado literario moderno, Boix está presente en casi cualquier exploración sobre el libro, la imprenta o la edición decimonónicos; sin embargo, hasta ahora no ha suscitado un estudio detenido y la información dispersa que sobre él se tiene es insuficiente para comprender el alcance de su figura. Para cubrir ese vacío, a través de la investigación hemerográfica, archivística y bibliográfica se ofrece un recorrido por su trayectoria biográfica, editorial y empresarial con el objetivo de ubicar a Boix en el mapa de la edición hispánica decimonónica.

Palabras Clave: Ignacio Boix, Historia de la Edición, Historia de la Imprenta, Historia del Libro, Comercio del Libro Español, Casas Editoriales, Historia Cultural y Literaria del Siglo XIX.

\section{AN «EDITOR INFATIGABLE»: IGNACIO BOIX'S BIOGRAPHICAL, EDITORIAL AND INVESTING TRAJECTORY}

AbStRact: Ignacio Boix y Blay was a bookseller, printer and editor who displayed an intense activity during the second third of the $19^{\text {th }}$ Century, mainly in Spain, but also in some strategic points of its overseas territories and Europe. Boix is a paradigmatic exponent of the modern Spanish publishing and typographic market, in a transitional stage between the ancient guild practices of the Old Regime and the creation of the new modern literary market. In fact, he is present in almost any exploration on the $19^{\text {th }}$ Century book publishing and printing; however, no comprehensive study on the topic has been conducted so far and the scattered information available about him is insufficient to understand the scope of this figure. To fill that gap, a journey through the biographical, editorial and investing trajectory of Boix is offered through hemerographic, archival and bibliographical research. The aim of this study is to place Boix on the map of the $19^{\text {th }}$ Century Hispanic edition.

KeYwords: Ignacio Boix, History of Publishing, History of Printing, History of the Book, Spanish Book Trade, Publishing Houses, $19^{\text {th }}$ Century Cultural and Literary History. 


\section{○. INTRODUCCIÓN}

Ignacio Boix es una de las figuras destacadas del mundo del libro en la España del siglo XIX. Su nombre está presente en casi cualquier historia de la edición, de la imprenta o del libro romántico, así como en estudios especializados sobre el segundo tercio de dicha centuria - la etapa en la que prioritariamente desplegó su actividad como editor, impresor y librero-. Hasta ahora, sin embargo, no se ha dedicado un estudio específico a su biografía ni a las prácticas que le permitieron consolidar un brillante imperio editorial durante la década de 1840. Tal ausencia de investigaciones justifica este trabajo, en el que se presentará un esbozo de semblanza biográfica de Boix para, posteriormente, analizar sus negocios editoriales, la diversificación de sus iniciativas empresariales, así como su política y su producción editorial a través de algunos hitos significativos. En definitiva, mediante la investigación hemerográfica, archivística y bibliográfica se ofrecerá una visión panorámica de la trayectoria biográfica, editorial y empresarial de Ignacio Boix, así como del papel que desempeñó en la historia de la edición española e iberoamericana. ${ }^{1}$

\section{i. Aproximación biográfica}

La vida de Ignacio Boix y Blay puede reconstruirse gracias al cruce de la documentación hallada en archivos con la información que arrojan las publicaciones periódicas, los testimonios de quienes trataron con él, las necrológicas y sus propias publicaciones especialmente, los pies de imprenta y los paratextos-, entre otras fuentes. Para comenzar esta investigación en la que se ha intentado sistematizar la información dispersa hasta ahora sobre Boix y profundizar en ella, además de presentar otra desconocida partiendo de los materiales mencionados, han sido esenciales varias fuentes primarias: por un lado, las necrológicas que aparecieron en la prensa tras su muerte; por otro, una semblanza de Boix como impresor elaborada por Serrano y Morales (I898-I899: 24-25, 73, I74); finalmente, una lámina litográfica de Rodríguez estampada en el taller de Aragón en i849 que retrata a Boix y que, además de ser la única imagen conocida que se conserva de él, incluye una nota manuscrita anónima con una biografía de siete líneas (Anónimo, 1849).

Este estudio, en todo caso, no es cerrado ni pretende agotar un tema que bien merece una monografía, en la línea de la que acaba de dedicar Martínez Martín (20I8) a Francisco de Paula Mellado. De hecho, las actividades editoriales y mercantiles de Boix y Mellado, quienes mantuvieron una rivalidad manifiesta, presentan notables paralelismos, en lo vital y en lo profesional: ambos fueron ambiciosos y polifacéticos hombres de negocios; construyeron poderosos imperios editoriales, con un volumen ingente de periódicos, revistas y libros; se adentraron en las sociedades especulativas del Madrid isabelino y apostaron por diversificar sus actividades, que excedieron el mundo del libro para alcanzar el papel, las minas, los minerales o los seguros; fueron reconocidos en su época con notables distinciones; jugaron gracias a sus casas editoriales un destacado papel en la difusión de las letras, la educación y la ciencia del siglo xix y ambos, a pesar de todo ello, estaban relegados al más completo de los olvidos.

I Este trabajo ahonda en los resultados iniciales ofrecidos en una serie de seis semblanzas sobre Boix y su círculo para Editores y Editoriales Iberoamericanos (siglos XIX-XXI)-EDI-RED (Peñas Ruiz, 20I7a-f), portal de la Biblioteca Virtual Miguel de Cervantes fruto de la Red Temática de Excelencia del MINECO Redes Transatlánticas: Prácticas editoriales de la Re(d)pública Iberoamericana FFII20I5-71940-REDT -P. Fernández, dir.-. En las citas de los archivos, periódicos y revistas consultados se usarán siglas para evitar repeticiones; la leyenda se ofrece en la bibliografía final. 
El objetivo de las siguientes páginas es paliar dicho olvido en lo tocante a Boix iniciando una primera aproximación a su figura y a su papel en el campo editorial y literario español de la primera mitad del siglo xIX.

\section{I.I Nacimiento y primeros pasos}

Los orígenes de Ignacio Boix se sitúan en Tarragona; así se indica, aunque sin fecha de nacimiento, en la nota manuscrita al pie de su retrato (Anónimo, I849). Sin embargo, no han faltado quienes le han creído valenciano (Opisso, I908: 318; Llanas, 2004: Io6; Peñas, 2014: 197); incluso alguien tan informado como Mesonero Romanos, que además publicó con el editor la cuarta edición de sus Escenas matritenses, desconocía su origen: «era D. Ignacio Boix / un valenciano de perlas» (DAM, no I88, 7-5-1854: I). También en un estudio específico sobre la imprenta en Tarragona (del Arco, 1916: 193-194) se ignora su origen y se le menciona de pasada y con imprecisiones, mientras que en una reciente publicación sobre tarraconenses célebres no solo está ausente, sino que tampoco aparece en la entrada que sí se dedica, con errores, a su hermano Andrés (Güell, 20I4).

La documentación conservada en el Archivo Histórico Archidiocesano de Tarragona, concretamente, en el archivo de la parroquia de Santa María de la Catedral, permite trazar una primera reconstrucción del árbol genealógico de Boix. ${ }^{2}$ Sus padres, Ignacio Boix Aleu ${ }^{3}$ e Ignacia Blay Rabassa, ${ }^{4}$ se casaron el 7 de diciembre de 1806 ; un año después, el I7 de noviembre de I807, nació su primogénito, Ignacio, bautizado el I9 como Ignasi Lluis Andreu. Le siguieron María Rosa Teresa Jacinta (6-Io-I809), Anton Manel Jordi (22-4-I82I), Agustina Francisca Balbina (3I-3-I824), de la que Ignacio fue padrino, y Andreu Joseph Olaguer (7-3-1830). 5

Ignacio nació y creció en el seno de una familia dedicada a oficios humildes y artesanos. Su padre, hijo de un maestro carpintero, siguió la estela de su suegro y trabajaba como panadero; su madre era la menor de nueve hermanos de una familia de pescadores y payeses; solo su bisabuelo y su tatarabuelo paternos se alejaron de estos oficios, pues eran organistas. En este sentido, los comienzos de Ignacio Boix en el mundo tipográfico y

2 AHAT, Tarragona, Parroquia de Santa María de la Catedral, 7r66. Todos los registros de bautismos, comuniones, matrimonios y defunciones de la familia que se ofrecen pertenecen a este fondo documental, salvo que se indique expresamente.

3 Los abuelos paternos de Ignacio, el maestro carpintero Lluis Boix Bavot y María Ignacia Aleu Maseras, se casaron el 22-3-I777 y tuvieron al menos cuatro hijos: Lluis Martí Pau (7-I-I778); Isidro Andreu Joseph (29-4-I78I); Bernat Andreu Ignasi (4-2-I784), el padre de Ignacio, y Ramón Antonio Jaume (26-7-I786), además de una hija, Ignacia, que fue madrina de una hermana de Boix, María Rosa. Sus bisabuelos paternos fueron Lluis Boix Boixo, organista — hijo de Lluis Boix, también organista en Gandesa, y de Manuela Boixo-, y María Francisca Bavot Torrell — hija de Andreu Bavot, payés, y de Gertrudis Torrell—, casados el I3-4-I744, por un lado; por otro, Andreu Aleu Serrahima, panadero — hijo de Domingo Aleu, también panadero, y de Tecla Serrahima-, y Magdalena Maseras Alasá — hija de Ramón Maseras, payés, e Ignacia Alasá-, casados el 6-2-I757.

4 Los abuelos maternos de Ignacio Boix, Andreu Blay Elías, pescador, y Teresa Rabassa Soler, se casaron el 2I6-I76r y tuvieron nueve hijos: Andreu Volanti Bruno (6-Io-I762); Magdalena Josefa Teresa (г2-4-I766); Francisco de Paula Horton Andreu (2-5-I769); Francisco Pau (4-2-I772); Teresa Ventura Jacinta (9-2-I774); Rosa Antonia Matildis (16-3-I777); Gertrudis Paula Francisca (23-4-I780); Joseph Cudal Bonaventura (3-6-I784) e Ignacia Josefa Teresa, la madre de Ignacio (I2-7-I787). Los bisabuelos maternos fueron Joseph Blay, pescador — hijo de Joseph Blay, también pescador, y de Úrsula Tomás—, y Teresa Elías Talavera — hija de Joseph Elías, payés, y María Talavera-, por un lado, casados el 29-2-I729; y Valentí Rabassa, pescador — hijo de Gregori Rabassa, payés, y de Ángela Calderó-, y Jacinta Soler, por otro, casados el 4-2-I725 — hija de Pau Soler, payés, y de Jacinta, sin apellido registrado-.

5 La boda de sus padres, en AHAT, Liber decimus tertius, f. I4Ov. Los bautismos de Ignacio y María Rosa, en AHAT, Llibre XXI de baptismes, f. $50 \mathrm{~V}$ y f. $302 \mathrm{r}$, respectivamente; los de Anton y Agustina, en Llibre XXIII, f. $92 \mathrm{~V}$ y f. 245 r, respectivamente; el de Andrés, es Llibre XXIV, f. 303r. En los libros de comunión de esta misma parroquia están registrados otros tres hermanos, Joseph, Josepa y Agustina, pero no he logrado localizar sus partidas de bautismo. Tampoco he hallado rastro de un Luis Boix y Blay, cerrajero, que figura en una guía de Barcelona (Anónimo, 1863: 201). 
editorial son aún oscuros. Quizá empezó de la mano de la familia de impresores y libreros de Tarragona Puigrubí Canals, ya que unos hermanos Anton y Josefa Puigrubí figuran en 1820 como padrinos de su hermano Anton. ${ }^{6}$ Por otra parte, en los años en que Ignacio tenía edad de formarse y aprender un oficio la única imprenta activa en Tarragona era la de los Puigrubí, junto con la de los hermanos Berdaguer (del Arco, I9i6). Tampoco son conocidos por ahora los pasos que dio hasta dedicarse al comercio de libros en Madrid, ciudad a la que llegó en i829 y donde poco después abrió junto a Antonio Matton su primer negocio, una librería. Sí sabemos por un padrón municipal de I84I (AVM, Estadística, 3-IIO-I) que fue miliciano nacional del segundo escuadrón; él mismo aludió a sus servicios durante el Trienio al solicitar años más tarde, en I842, la Cruz de Carlos III (AHN, Estado, leg. 6289, 6).

Como en tantos otros casos, la estructura del núcleo familiar de Boix estuvo en gran medida integrada en su entramado empresarial. Lo demuestran los padrones municipales conservados en el Archivo de la Villa de Madrid, que arrojan mucha luz sobre este punto, si bien solo ofrecen un retrato de los años I84I a I847, ${ }^{7}$ cuando Boix estaba afincado en el cuarto principal del número 8 de Carretas, donde tenía la librería. ${ }^{8}$

En el primer padrón conservado, de I84I, figuran como habitantes Ignacio Boix junto a su mujer,Josefa Marco, natural de Valencia y residente en Madrid, como él, desde I829; ${ }^{9}$ Andrés Boix, que figura por error como hijo del matrimonio y natural de Barcelona -en lugar de como hermano de Ignacio y nacido en Tarragona-; dos jóvenes dependientes de la librería, Sebastián de la Cámara y Fernando Viana, y una sirvienta. ${ }^{\text {Io }}$ En I842 seguían viviendo los mismos, aunque Andrés Boix ya figuraba correctamente como su hermano (AVM, Estadística, 3-109-2). En I844 vivían con el matrimonio Boix Eduardo Matton, «sobrino», estudiante de I4 años y residente dos años en Madrid; Antonio Ortigosa, dependiente, de 21 años, soltero, de Zaragoza y residente tres años en Madrid; dos jóvenes dependientes de la librería, un matrimonio y una joven soltera sin aparente conexión familiar ni comercial; este padrón está firmado por el propio Boix el I3 de abril de I844 (AVM, Estadística, 3-99-I). En I847 figura por primera vez el único hijo del matrimonio, Emilio Boix, nacido en Madrid el I9 de abril de I84I, junto a Ángela Matton, prima, nacida en Valencia en I828, y un criado ${ }^{\text {II }}$ (AVM, Estadística, 2-355-II). Finalmente, el padrón de 1848 registra que Boix, «del comercio de libros», «se halla ausente por poco tiempo» y constan como habitantes su mujer e hijo junto a dos sirvientes y Ángeles Matton, «sobrina» (AVM, Estadística, 2-359-II).

La mujer de Boix, Josefa, debió de tener alguna participación en los negocios, a la luz de varios testimonios, como el padrón de i847, que le asigna la misma profesión del

6 AHAT, Liber XXIII de baptismes, f. 92v. El impresor Miquel Puigrubí Riera, de Sant Feliu de Torelló, se casó el 8-I2-I788 con Antonia Canals, hija del impresor de Tarragona Pere Canals y de María Ollé (AHAT, Llibre de desposoris que comensa el dia 3 de febrer de 1765, f. $347 \mathrm{v}$ ); tuvieron varios hijos, entre los que figuran una Francisca y un Antonio. Los padrinos del hermano de Ignacio podrían ser estos hermanos, o bien familiares suyos.

7 Boix está inscrito en los padrones correspondientes a la calle Carretas que se conservan en el Archivo de la Villa de Madrid en los años I84I, I842, I844, I847 y I848. Del año I843 no se conserva información y de I846 no constan datos sobre la finca. En 1849 ya no vivía allí: la casa figura como «desalquilada» (AVM, Estadística, 2-365-I). Fue ocupada por el farmacéutico Isidro Mir y por un estudiante en I85I, quienes abrieron una botica (AVM, Estadística, 2-380-7).

8 En Carretas, 8 vivía presumiblemente desde I838, año en que abrió la librería, como prueban los pies de imprenta de sus publicaciones y la nota biográfica contenida en su retrato anónimo.

9 Posiblemente se casaron en torno a esta fecha.

io Cuatro años después Fernando Viana, natural de Poyos, tenía un puesto de libros en la plazuela de la Provincia (BBEE, año VI, $\mathrm{n}^{\circ}$ 3, I-2-I845: 46). En otro cuarto del 8 de Carretas, por cierto, vivía el librero Ramón Matute con su mujer e hijos (AVM, Estadística, 3-IIo-I).

II Es el primer padrón con mención expresa a fechas de nacimiento. Registra la fecha de bautizo de Ignacio Boix por error (I9-II-I807), en lugar de la de nacimiento - el I7-; Josefa nació el I3-8-I8I2 y el hijo de ambos, Emilio, el I9-4-I84I; en el padrón del año siguiente las fechas bailan, pues señala que la mujer nació en i8Io y el hijo, en I840. 
marido, o un singular soneto que Juan Eugenio Hartzenbusch le dedica, de parte de los regentes y operarios del taller, con motivo de su cumpleaños; la composición se conserva entre los papeles inéditos del autor y parece revelar la presencia e impronta de la mujer de Boix en el establecimiento (Hartzenbusch, s. a.). ${ }^{\mathrm{I2}}$ Por otra parte, Ignacio contó con sus hermanos Antonio y Andrés para sus sociedades y redes comerciales. El pequeño, Andrés, se trasladó a Madrid con solo diez años para formarse en el local de Carretas; algunos años después, cuando Ignacio se marchó a París, ese aprendizaje le permitió establecerse en México como impresor, editor y librero (Peñas, 20I7f; Güell, 20I4: 34). Idénticos pasos siguió Juan Antonio Ortigosa, también acogido por el matrimonio Boix, quien empezó como dependiente de su librería para convertirse después en impresor, socio de los tres hermanos Boix (RMM, I848: 33) y enlace de contacto de Ignacio en Madrid cuando este se marchó de la capital; les unían, además, lazos familiares: en abril de I86o, en una carta dirigida desde su imprenta de Valencia a Leopoldo Augusto de Cueto, Boix se refería a Ortigosa como «mi sobrino» (en del Rey y Lera, 1999: 44I). Finalmente, los hermanos Matton que vivieron con los Boix eran Eduardo y Ángela Matton y Marco, hijos de Antonio Matton y de una hermana de la mujer de Boix, Josefa Marco. ${ }^{13}$ Ángela quizá colaborara de algún modo en la empresa, pues un padrón la identifica como "propietaria», al igual que al matrimonio, cuando aún era soltera, ${ }^{14}$ mientras que Eduardo, que en I844 todavía vivía con Boix, lo hizo con toda seguridad: se marchó a Caracas con su padre en marzo de $1847^{15}$ para gestionar personalmente la Librería de Boix y Compañía (Boix y Cía., I846; $C d P$, no 27, 22-I-1847: s. p.). La experiencia de los Matton como encargados de Boix en Caracas no duró mucho, pues en 1848 Antonio Matton ya estaba en Valencia, al frente de otra librería (Anónimo, i848), también, aparentemente, de escaso recorrido. En I855 fue nombrado comandante del presidio de Valencia ( $L E p$, no 2009, 2-Io-I855: 4), retomando así un cargo que ya había ostentado en el Presidio Peninsular de Barcelona desde septiembre de I84I (Saurí y Matas, 1842: 87) hasta septiembre de I843, cuando fue detenido y posteriormente reemplazado debido a un incidente ocurrido durante la revuelta progresista contra el gobierno de Joaquín María López. ${ }^{16}$ En cuanto al hijo de Boix, Emilio, trabajó en la redacción de al menos uno de los periódicos de su padre ( $L C A$, $\mathrm{n}^{\circ}$ 355, I8-8-1859: 4). Todo ello evidencia que Boix integró de un modo u otro a varios familiares en su entramado tipográfico-editorial, aunque sin llegar a fundar una saga; de hecho, su negocio no subsistió tras su muerte. ${ }^{17}$

En Madrid, donde residió entre 1829 y I851, siempre se movió en los espacios urbanos de Sol y alrededores, punto neurálgico del comercio de libros en la capital. Así, sus librerías e imprentas estuvieron sucesivamente en Carrera de San Jerónimo, Preciados,

I2 La poesía lleva por título y encabezado «Cuentes el día de hoy cien y cien veces. Soneto.-A doña Josefa Marco de Boix en sus días, los regentes y operarios. Año de I845»; es una hoja suelta autógrafa — reproducida del originalconservada en el fondo Hartzenbusch de la BNE (Hartzenbusch, s. a.). Se encuentra descrita en la Bibliografía de Hartzenbusch (Hartzenbusch e Hiriart, I900: 209).

I3 Así lo hacen pensar el apellido y la indicación de «sobrinos» en los padrones; Boix y Matton serían, por tanto, cuñados. Queda por determinar aún el papel que desempeñó Antonio Matton en el despegue inicial de Boix en 1830, una década antes de que Fagoaga le aupara definitivamente con sus créditos millonarios.

I4 En 1868 se concede a Ângeles Matton una pensión de Montepíos: «Doña María de los Ángeles Matton y Marco, de estado viuda, hija de don Antonio, Comandante que fue de Presidios. Se le declara la de 225 escudos anuales» ( $G M$, año 207, no 98, 7-4-1868: 7).

I5 La prensa se hace eco de que Antonio Matton y su hijo "parten para Ultramar» ( $C d P, n^{\circ}$ 47, 8-3-I847: s. p.).

I6 Fue acusado de haber tomado parte en una conspiración para permitir la entrada de tropas por el presidio, por lo que fue detenido el 24 de septiembre junto a dos capataces y expulsado de la ciudad, aunque no se pudo probar nada contra él (Anónimo, 1843: 39).

I7 En una de las notas necrológicas tras su muerte se indica que Boix murió arruinado y que dejó a su viuda y su hijo desamparados y sin recursos ( $L I$, año Ix, $\mathrm{n}^{\circ} 2272,17-4-1862: 3$ ). 
Carretas, Alameda, Rejas, Puerta del Sol y Capellanes. Cuando a finales de I85I probó suerte en París, también lo hizo en enclaves destacados: en la Rue Le Peletier, donde entonces estaba instalada la Ópera de París, abrió una primera librería española y después, un gabinete de lectura en la calle Richelieu, frente al lujoso Hotel de Príncipes, que conocía bien por haberse alojado en él durante un par de meses de I849 (Hortelano, I936: I80-18I). La experiencia parisina de Boix apenas duró cinco años y estuvo llena de dificultades. Tras el fracaso de las iniciativas que había tratado de promover allí, se vio abocado a regresar España en torno a 1856. Esta vez se asentó en la ciudad natal de su mujer, Valencia, donde abrió una nueva imprenta y una fundición de caracteres con los que intentó repetir sus éxitos de los años 40 en Madrid, pero nunca volvió a disfrutar de su antigua posición. Cuando poco después murió, en 1862, estaba en una situación precaria, pero seguía ejerciendo la actividad a la que consagró toda su vida.

\section{I.2 Un episodio de la vida intima de Boix}

En cuanto al plano más íntimo de Boix, algunos testimonios revelan datos de interés. Destacan las memorias de José Zorrilla, escritas desde la perspectiva de las tensas relaciones entre el autor y sus editores, pero, especialmente, las del impresor y editor Benito Hortelano, que ofrecen un testimonio directo sobre la vida privada de Boix. ${ }^{18}$

Hortelano, que de joven había trabajado en la imprenta de Boix (1936: 43), evoca un episodio significativo donde muestra «la amistad y respetos» que sentía por su «antiguo maestro, Boix» (I72) a propósito de un viaje que hizo a París en julio de I849: en la diligencia, según cuenta, coincidió con «la bella Antoñita Coronado de Llorente», que iba con su criada a Bayona y que, como después revela, era la amante de Boix. Natural de Jaén y de familia muy humilde, Antoñita era hija de un portero de Aniceto de Álvaro, comerciante y funcionario de Hacienda que fue fundador, editor y director del periódico El Castellano y de su imprenta. Hortelano relata que de Álvaro fue el amante de Antoñita, una niña por aquel entonces, hasta el momento en que ella decidió «entregarse a otro viejo (...), D. Ignacio Boix, célebre editor de Madrid, hombre generoso, gastador y que cifraba su orgullo en robar las muchachas más lindas a sus amantes a fuerza de dinero y atenciones» (I7I); más adelante, insiste: «Boix es hombre espléndido, aficionado a las comodidades, y le agrada mucho hacer papelón» (I79-I80). Zorrilla confirma el testimonio de Hortelano al afirmar, a colación de la quiebra del editor en París: «Boix pudo establecer el comercio de libros en España, y hacerse el primer editor nuestro y ganar millones; pero tenía un flaco: las mujeres. Catorce días antes de expirar el plazo de mi primer pagaré vendió a los Garnier, hermanos, el periódico El Eco de Ambos Mundos, y quebró» (I882b: 58; la cursiva es mía). ${ }^{19}$ Otro juicio anónimo presentaba al editor como «decidor», «jovial» $\mathrm{y}$ «expansivo» ( $L I$, año IX, no 2272, I7-4-I862: 3).

Siguiendo el relato de Hortelano, Boix llegó a Bayona para encontrarse con «su querida» e ir «a tomar los baños del Pirineo, que le habían ordenado los médicos por una enfermedad a la piel que padecía» (172). Siguen unas páginas donde narra sus experiencias parisinas, sus contactos con emigrados españoles y las visitas al impresor Albert o a Clémentine Denné Schmitz, «madame Smit (sic), librera y comisionista de los editores de Madrid» (I74). Al mes de su estancia en París Ignacio y su amante llegaron para visitar

I8 Boix no pudo conocer estos relatos, pues murió en i862. Zorrilla empezó a publicar sus recuerdos en Los Lunes del Imparcial a partir del 6 de octubre de I879 (Caballé, 1998: 359), mientras que las memorias de Hortelano, escritas en I86o durante su exilio en Buenos Aires, no vieron la luz hasta I936, cuando las publicó Espasa Calpe en Madrid. Véase Ménguez (2007).

I9 A esta quiebra se refiere Zorrilla de nuevo en otro lugar de sus memorias, a propósito de su Granada (I882a). 
a un famoso especialista de enfermedades de la piel, Velpeau, a quien el editor pagó más de 6.000 francos, aunque no logró curarle; lo hizo un médico que viajaba con el propio Boix, según relata Hortelano:

Acompañaba a Boix un cirujano valenciano, practicante que había sido en el Ejército y en varios hospitales de España. Infinitas veces le había propuesto a D. Ignacio el curarle; pero éste le llamaba bestia, estúpido y majadero, diciéndole que, no habiendo podido curarle Velpeau, el padre de la ciencia, cómo quería él curarle. Por fin, cansado de cambiar de médicos, y como a la desesperada, se puso en manos del practicante que como de sirviente o enfermero estaba. Ocho días fueron suficientes al estúpido cirujano, al bestia practicante español, como Boix le llamaba, para poner completamente sano a su patrón, desapareciendo la incurable enfermedad de la piel que le había convertido, con los medicamentos y unturas, en una llaga todo el cuerpo.

Pero lo más particular de esta cura fue la sencillez de los remedios que el cirujano propinó; fueron estos un purgante, varios baños enteros en agua de afrecho con algunas partículas de mercurio, con lo que las llagas desaparecieron y la piel quedó sana, desapareciendo la picazón que tanto le molestaba. Este mismo remedio pudo haberlo usado en Madrid si hubiese dado oídos a su practicante, pero la ofuscación que se apodera de los hombres por el relumbrón de la fama de los charlatanes le hicieron gastar más de 3.000 patacones, las molestias del viaje y una enfermedad larga, que, si no le hubiera conducido a la tumba, le hubiera conducido a la indigencia por la mala fe o la ignorancia de los célebres médicos (Hortelano, I936: I8I).

Tras la cura, aún convaleciente, el editor pidió a Hortelano que lo acompañase un tiempo; así, estuvieron juntos «más de dos meses, viviendo en el mismo hotel de Príncipes, hasta que se mejoró» (18I). En ese tiempo Hortelano, Boix y Antoñita visitaron el palacio de Versalles y la fábrica de porcelana de Sèvres, pasaron dos días de campo en Saint-Cloud y acudieron a teatros y jardines públicos, así como al Observatorio Astronómico. Además, visitaron «los principales establecimientos tipográficos y fábricas de fundición de prensas, teniendo ocasión de examinar el sistema interior de estos establecimientos» (I82). En torno a diciembre de 1849 Hortelano y Boix, que regresaba a Madrid, se despidieron en Burdeos, pero siguieron en contacto e incluso Boix le ayudó cuando se marchó a Buenos Aires: «A los seis meses recibí ocho cajones de libros de D. Ignacio Estivill, antiguo corresponsal mío en Barcelona, y ocho que Sanglas tenía de D. Ignacio Boix. Con estos libros establecí un depósito (...)» (194); Hortelano también fue corresponsal y comisionado de El Eco de Ambos Mundos de Boix desde 1852 hasta que el editor quebró en I855 (270) y a finales de I857 seguían en contacto, pues Hortelano afirma que acogió dos meses en su casa a Dionisio Lirio, quien fue recomendado por el editor (287).

Estos testimonios de Zorrilla y Hortelano permiten asomarse a una escena privada de la vida de Boix. Las siguientes páginas, en cambio, se centrarán en un ámbito muy diferente: abordan las fases de la trayectoria profesional de Boix, así como algunos hitos de su producción tipográfica y editorial.

\section{FASES DE LA TRAYECTORIA DE BOIX COMO LIBRERO, IMPRESOR Y EDITOR}

La actividad de Ignacio Boix como librero, impresor y editor, insuficientemente conocida hasta la fecha, ejemplifica bien la evolución de las prácticas de producción, 
publicación y difusión de libros en el siglo XIX. ${ }^{20} \mathrm{El}$ recorrido por las fases de su labor transcurre de forma prácticamente simultánea a las etapas del proceso de transformación del antiguo régimen tipográfico en el mercado editorial moderno, en el marco, además, de la paulatina profesionalización de autores y editores (Martínez Martín, 2009: 37-44). Así, en su trayectoria se pueden apreciar tres estadios más o menos diferenciados. El primero comprende casi toda la década de I830, coincidiendo con ese periodo de 1800 a I 836 donde conviven las antiguas prácticas gremiales con los aún muy tímidos avances técnicos. Boix emerge en el circuito madrileño del comercio de libros en I830 y se hace hueco en él junto a Antonio Matton, con quien funda en ese año la efímera Casa de Matton y Boix, con librería primero e imprenta después, para, a continuación, establecer por su cuenta en el verano de 1833 la Imprenta de Ignacio Boix y la Casa Boix, cuyas primeras publicaciones importantes datan de I838-1839. El segundo estadio abarca la década de los 40, cuando, a la vez que se consolida gradualmente el mercado literario nacional, las iniciativas editoriales y especulativas de Boix viven su periodo de máxima efervescencia; esta es la etapa de madurez del editor, que convierte su antigua imprenta en un establecimiento reputado y moderno, con imprenta, grabado, estereotipia, litografía y tipografía musical. Entre I846 y I848, en cambio, el editor va a sufrir importantes reveses coincidiendo con el fracaso de las sociedades anónimas y con la crisis de 1848 y de su principal prestamista, todo lo cual lo lleva a la quiebra. Finalmente, la tercera etapa comprende desde ese momento hasta I862, el año de su muerte, es decir, atraviesa toda la década de 1850; esta es una fase marcada por los intentos de Boix para reactivar su maltrecha economía, primero en París, donde sufrió una segunda quiebra importante, y después en Valencia, donde abrió su último establecimiento tipográfico.

\section{I Los inicios: la Casa de Matton y Boix y el nacimiento de la Casa Boix}

Boix llegó a Madrid en 1829, con 22 años, y dio sus primeros pasos junto a Antonio Matton y Curtoys, con quien abrió una librería que se anuncia ya en febrero de 1830 . El local, ubicado en la Carrera de San Jerónimo, había pertenecido al librero Manuel Barco García (DAM, nº 9I, I-4-I830: 364), hijo del impresor Plácido Barco y de Bernarda García, su primera mujer (Rodríguez-Moñino, 1945: 65). Matton y Boix comenzaron vendiendo novelas populares, comedias, sainetes y libros instructivos. Adquirían la propiedad de traducciones de obras extranjeras, sobre todo novelas francesas, que después vendían a impresores como Jordán, Espinosa o Burgos (Peñas, 20I7b). Su catálogo de obras fue en aumento (Matton y Boix, I830, 183I) e incluía traducciones de novelas inglesas y francesas, guías de urbanidad o tratados de gramática y ortografía.

El salto a la impresión de sus propias obras no tardó en llegar, pues en mayo de 1832 sacaron las Auroras de Flora, o colección de historietas y novelas morales adornada con láminas finas en la nueva Imprenta de Matton y Boix, presentada ya como "propiedad de la casa de Matton y Boix»; esta obra dio paso a otros títulos entre I832 y I833. Sin embargo, ya en el verano de 1833 Boix empezó a figurar solo al frente del negocio. En junio se anunciaron obras «en la librería de Boix, Carrera de S. Jerónimo, no Io» (ECPLM, no 766, 3-6-1833: 4) y apareció su primer catálogo de caracteres, emblemas y adornos (Boix, I833). De la imprenta de Ignacio Boix salieron obras entre 1833 y 1835; no obstante, Matton seguía vinculado a ella, como evidencia la quiebra de la sociedad poco más tarde. En efecto, el II de marzo de I835 se celebró una «junta de acreedores a la quiebra de los Sres. Matton y

20 Pueden verse al respecto las semblanzas publicadas en EDI-RED sobre este impresor y su círculo (Peñas Ruiz, 20I7a-f). 
Boix» que, por falta de peticionarios, volvió a fijarse el día 20 en la Casa Consular ( $D A M$, $\left.\mathrm{n}^{\mathrm{o}} 75, \mathrm{I} 7-3-\mathrm{-1} 835: 3\right)$.

Tras esta experiencia inicial, Boix encontró una salida junto al comerciante e impresor Mariano de la Paz García, quien lo colocó al frente de su imprenta entre 1835 y I838, el único periodo en que Boix parece haber trabajado para otro; ; $^{21}$ así se refleja en los pies de imprenta de las obras que lanzó estos años, de carácter político, jurídico o de circunstancias, donde aparece «Imprenta a cargo de I. Boix», «Imprenta de don M. García, a cargo de don I. Boix» e «Imprenta de don M. P. García a cargo de don I. Boix». Además, Boix sucedió en esta época a de la Paz en el cargo de editor responsable del progresista Eco del Comercio, puesto que desempeñó entre el 7 de enero y el 3 I de marzo de $1838 .{ }^{22}$ Precisamente, 1838 es el año que marca un giro en su actividad, pues vuelve a imprimir bajo su nombre - Imprenta de Ignacio Boix-, sobre todo folletos, opúsculos políticos y obras históricas, muchas por encargo; es también este el momento en que se traslada de Preciados, I9 al que será su enclave más representativo, Carretas, 8, y empieza a estampar en sus publicaciones el sello «Es propiedad de la Casa de Boix».

Entre 1838 y 1839, sin abandonar las obras políticas e históricas, Boix se abrió paso con sus primeras publicaciones periódicas, con obras literarias originales como el Manual alfabético del Quijote de Mariano de Rementería y Fica o el Astolfo Federico de Madrazo, con traducciones de autores franceses como Aulnoy y Balzac, así como con la Colección de novelas escogidas de Josefa Álvarez de Segovia y Los prisioneros de Abd-el-Kader en versión de Ramón de Castañeira. En I839 se sumó, además, al negocio de las publicaciones teatrales a través de su Repertorio Dramático.

Las publicaciones que salieron de la imprenta de Boix en estos años son aún rudimentarias y de escasa calidad tipográfica, pero supusieron la antesala de los avances técnicos y editoriales que alcanzó su establecimiento en los años 40.

\subsection{Los años dorados (I840-I846)}

Los años de I840 a I846 fueron el momento de máxima plenitud personal, editorial y empresarial de Boix: en esta etapa accedió a las principales instituciones del momento, estableció relaciones comerciales y personales con destacados personajes de la cultura y la política, se implicó en actividades ajenas al mundo del libro, amasó una capital considerable y logró, en fin, situarse como uno de los editores más destacados del Madrid isabelino. Tal ascenso estuvo muy relacionado con su amistad con el banquero Joaquín de Fagoaga, director del Banco de San Fernando (Anónimo, 1849), de quien obtuvo cuantiosos préstamos para impulsar sus negocios (AHPM, «Escritura de cesión y obligación con hipoteca de varias fincas en Cuenca, D. Ignacio Boix, al Excmo. Sr. D. Joaquín Fagoaga», Protocolos de D. José de Celis Ruiz, I847, leg. 25645), pero también con el propio desarrollo de la industria y con los esfuerzos del editor por introducir máquinas, personal y técnicas del extranjero. Gracias a todo ello, Boix pudo en estos años lanzar obras ya muy alejadas de su primitiva labor editorial y tipográfica de la década anterior. Igualmente, fueron esenciales los apoyos gubernativos que recibió, singularmente, la autorización para reimprimir y

2I Me refiero, claro, a los años que van de I830 a I862; en la etapa anterior, sobre la que no he podido aclarar gran cosa, Boix pudo formarse en una imprenta. De la Paz solicitó en 1836, cuando Boix era su regente, el privilegio de introducción de la primera máquina continua española para fabricar papel (Gutiérrez-Poch, 20I6: 36).

22 En esa etapa Boix publicó un suplemento con un artículo de Juan Álvarez Mendizábal por el que fue denunciado y llevado a juicio en calidad de editor responsable; el propio periódico se hizo eco de los detalles del proceso entre el I de abril y el 6 de mayo de I839; gracias a uno de los artículos, que reproducía la declaración de Boix, pude datar la fecha de nacimiento para localizar su partida de bautismo (EC, no I798, 3-4-I839: 4). 
vender por su cuenta la Recopilación de Leyes de Indias que se le concedió por Real Orden de 16 de diciembre de 1840 (Colección, I84I). A este lucrativo beneficio hay que añadir otra fuente segura de ingresos, el Diario de Avisos, cuya impresión ganó Boix en subasta el I de octubre de I84I por un desembolso mensual de 21.600 reales y anual de 259.200 (Mesonero Romanos, I842: I79) y que tuvo a su cargo hasta el i de noviembre de i847, cuando lo relevó José María Alonso ( $E C, \mathrm{n}^{\circ}$ II58, 28-Io-I847:3) ${ }^{23}$ Asimismo, Boix concertó acuerdos con organismos oficiales y adquirió privilegios exclusivos para la edición e impresión de calendarios y de textos jurídicos y educativos como el Código de comercio extractado, obra que «se ha recomendado por la Dirección general de Estudios y se ha señalado por texto en la mayor parte de colegios y universidades» (Boix, I842: 318); el Febrero o librería de jueces, abogados y escribanos, «recomendada por la Dirección general de estudios y se da por texto en todas las universidades del reino» (319); las Fábulas en verso castellano para uso de las escuelas compuestas de Samaniego, impresas por orden de la Inspección General de Instrucción Pública y con privilegio real exclusivo o la mencionada Recopilación.

En estos años Boix dio a luz sus ediciones y publicaciones periódicas más populares: el Panléxico, la Galería de hombres célebres contemporáneos, Los españoles pintados por sí mismos, El Entreacto, Revista de Teatros o El Laberinto. Fueron los años de las colecciones, las grandes tiradas y la multiplicación, en fin, de libros, diarios y revistas. Comenzó a hacerse hueco entre 1840 y 1842 con sus publicaciones y con obras originales de autores españoles como El diablo mundo de Espronceda; los Cantos del trovador y las Vigilias del estío de Zorrilla, que pagó por adelantado (Zorrilla, I880: I30; Alonso Cortés, I917: 357358); los Viajes de Salas y Quiroga o las poesías de García Gutiérrez, Miguel Agustín Príncipe, Mariano de Rementería y Campoamor. Al tiempo, Boix centró sus esfuerzos en las colecciones y en la prensa, sabedor de su potencial como fuente de ingresos y elemento de captación de público en forma de suscripciones. También sacó rédito de los autores a quienes editaba colocándolos en las redacciones de sus periódicos y revistas; es el caso de Jacinto de Salas y Quiroga, a quien en I84I puso al frente de su liberal Revista del Progreso (Hartzenbusch e Hiriart, 1894: 72) tras haber editado un año antes sus relatos de viaje, o de Ramón de Castañeira, cuyos servicios como traductor había empleado en I838 y a quien recurrió de nuevo en I843 para sus Españoles pintados; ${ }^{24}$ por su parte, Juan Martínez Villergas publicó con el editor varias de sus obras entre los años 40 y 50 y fue redactor de la revista literaria que impulsó en París para lectores de Ultramar, mientras que Antonio Ferrer del Río comenzó a trabajar con Boix cuando aún era un joven taquígrafo de las Cortes y llegó a tener tan estrecha relación con él que este lo comisionó para abrir sucursales de su casa editorial en Cuba y México; así lo evoca Zorrilla (I880: I27), ${ }^{25}$ que reconoció «la honradez y laboriosidad que observó Ferrer en sus negocios mercantiles con Boix, y que le acarrearon una buena posición» (Alonso Cortés, 1917: 362). Estos son solo unos ejemplos de los trasvases que contribuyeron a crear una red intelectual en torno a Boix.

En los seis primeros años de la década de I840 el editor transformó su antigua imprenta en el establecimiento tipográfico que dio celebridad a su casa editorial, conocida como de don Ignacio Boix o como Casa Boix, aunque el nombre más popular, su «marca personal»,

23 En la ficha bibliográfica de la Hemeroteca Virtual de la Biblioteca Nacional de España se ignora la participación de Boix como editor e impresor del Diario durante estos años: se pasa de Jordán y su viuda e hijos a la Sociedad Literaria Tipográfica de la Ilustración — tras la que, por cierto, también estuvo Boix-.

24 Ucelay atribuyó erróneamente la introducción de esta obra a Boix (I95I: Io8); en realidad, es de José María Andueza (Peñas, 20I4: 210). También se desconocía que Boix encargó a Ferrer del Río la dirección de la parte literaria y a Calixto Ortega, la parte artística (209).

${ }_{25}$ Zorrilla lo llama $X$, pero Alonso Cortés revela su identidad (I9I7: 360). 
siempre fue «Boix, Editor». ${ }^{26}$ Durante esta etapa Boix gestionaba la imprenta en Rejas, $4{ }^{27}$ y estuvo asentado de forma estable en Carretas, $8-0$ 27, dado el cambio de numeración de estos años-. Este último edificio alberga en la actualidad un conocido restaurante de comida rápida, pero se conserva tal cual lo planificó Boix en I845, año en que presentó un proyecto para reformar la fachada antigua (AVM, 4-62-19). A su vez, sabemos cómo era el edificio en el momento en que Boix abrió su librería en 1838 gracias al anterior expediente de edificación, de agosto de I795: un representante del convento de Santa Bárbara solicitó entonces demoler la antigua casa, que había pertenecido al convento de los Padres Mercedarios Descalzos y a la que correspondían los números i3 y I4 (Planimetría, I988: I72), para construir una nueva (AVM, 4-62-I9). Así, podemos observar el pasado y el presente del que fuera taller de imprenta y librería de Boix desde finales del siglo xviII hasta 2018.

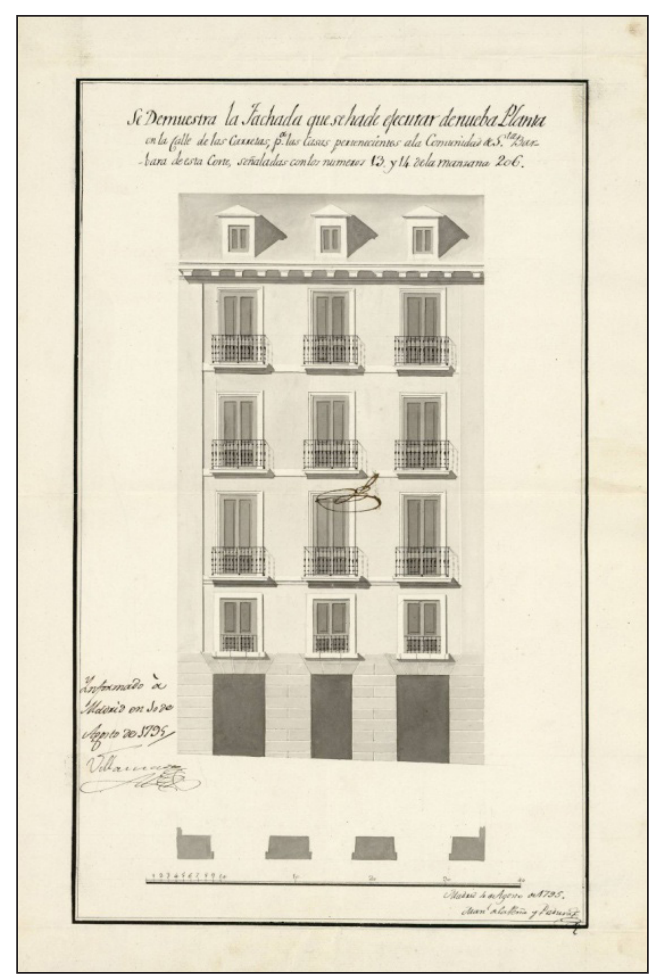

Expediente de edificación de la casa de Carretas, n I3-I4 (después, no 8), año I795 (AVM, 1-54-45)

26 Se trata de la imprenta del Diario de Avisos.

${ }_{27}$ En sus pies de imprenta la referencia habitual era Carretas, 8, aunque tenía la imprenta en Carretas, 27 y gestionaba la «del Diario de Avisos» en Rejas, 4 . 


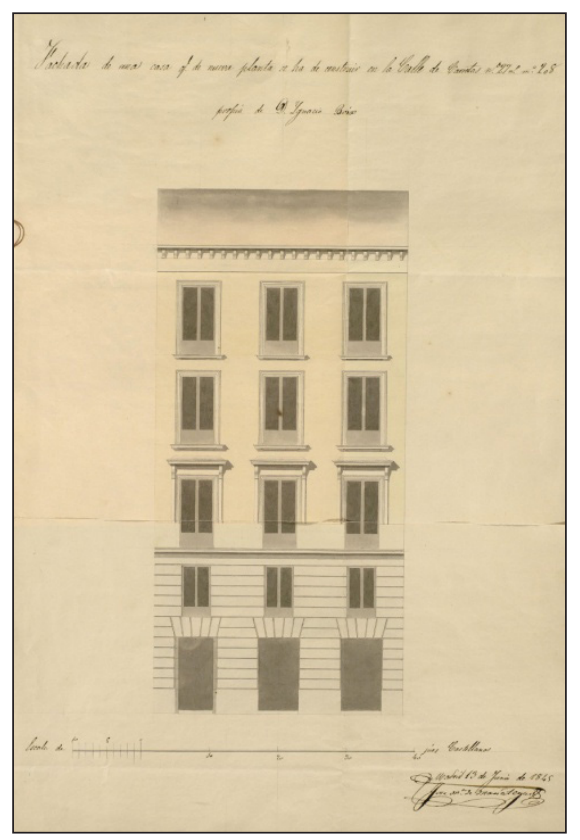

Proyecto presentado por Boix en I845 para remodelar la fachada de su librería en Carretas, 8 (AVM, 4-62-I9)

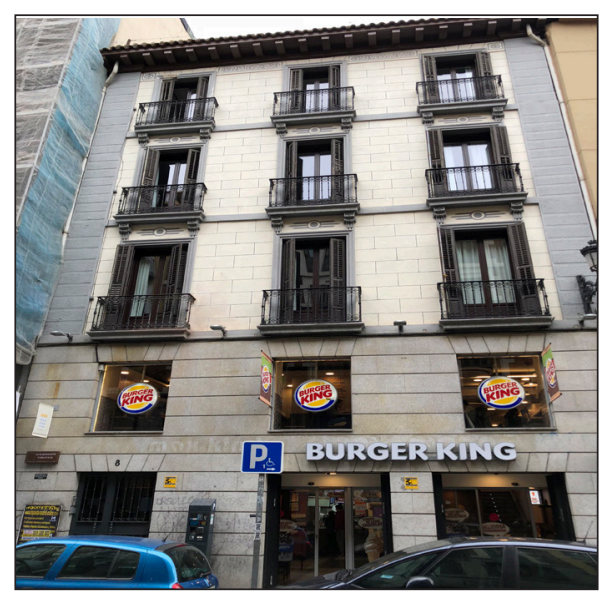

Estado actual de la librería de Boix en Carretas, 8 (Fotografía de la autora)

Entre las mejoras que Boix fue introduciendo en su establecimiento se encuentra el cambio de ubicación, pues requería un espacio más adecuado para, junto a otros enseres, las tres máquinas de imprimir que adquirió en 1843 , «entre ellas una nuevamente construida en París, y que por confesión del mismo inventor no hay más que otra igual montada en Francia» (EC, $2^{\mathrm{a}}$ ép., no 216, 4-4-1843: 3). Contaba también con varias prensas de hierro y madera y dos máquinas de satinar; por todo ello, su imprenta se llegó a considerar como «sin disputa, la más bien surtida de cuantas existen en Madrid» $\left(E C, 2^{\mathrm{a}}\right.$ ép., ${ }^{\circ}$ 216, 4-4-1843:3). Así, en mayo de I844 se anunció la «mudanza de las oficinas tipográficas del señor Boix» ( $D M, \mathrm{n}^{\circ}$ 198, 16-5-1844: I), cuya nueva ubicación se apuntó un mes más tarde en una crónica anónima que describía la visita al local (CP, nº 37, I2-6-1844: 4). 
Se trata de la calle Alameda, en cuyo número a abrió la librería, reservando el 3 para la flamante imprenta con estereotipia, fundición, grabado y litografía.

A sus negocios de imprenta y librería en Madrid hay que sumar los que tuvo fuera de la capital: por un lado, la Imprenta de Ignacio Boix, que abrió en el número 2I de la calle Mayor de Tarragona en I844 y que estuvo activa al menos hasta 1849, con Ramón Mallol como regente (del Arco, I916: 193); por otro, las librerías en España y Ultramar, que llegaron a ser ocho en I844 y que estuvieron en Madrid - Carretas, 8-, Barcelona — calle de San Miguel; después en Unión, I7-, Sevilla -Carpinterías, 20-, Tarragona —calle Mayor-, La Habana — calle de Cuba-, Caracas - Comercio, 37- y Valparaíso —eran depósitos de librería, en los casos de Venezuela y Chile-. Además, contó con una extensa red de puntos de suscripción en las principales librerías del país, así como de corresponsales; en I845 ascendía a a la considerable cifra de 156 puntos ( $E T, \mathrm{n}^{\circ} 4 \mathrm{I3}$, I9-7-I845:4). El 4 de abril de ese mismo año, precisamente, Boix inauguró en Carretas, 35 la Librería Moderna, que pretendía convertir en «librería universal española moderna» y donde dio preferencia a las obras españolas, a los devocionarios con variedad de encuadernaciones y a «las mejores colecciones de novelas, tanto españolas como traducidas de los autores más acreditados» $\left(D M, \mathrm{n}^{\circ} 320,4^{-4}-\mathrm{I} 845: \mathrm{I}\right)$.

En estos años Boix se embarcó en diferentes proyectos con Fagoaga, comenzando por la Caja de Ahorros de El Iris (I843), después Compañía General del Iris (I844), una sociedad anónima destinada a asegurar las cosechas y el reemplazo militar de la que este banquero fue fundador y presidente. Boix, por su parte, fue socio accionista, miembro de la Junta de Gobierno y segundo vicesecretario de la Junta General; además, se encargó de imprimir los estatutos de la compañía (Compañía, 1844)..$^{28}$ Otro negocio especulativo que aunó a Boix y Fagoaga fue la Sociedad Palentina Leonesa, que explotaba el carbón y el hierro de las minas de Sabero; ambos formaron parte de su Junta de Gobierno y Boix, de nuevo, imprimió varios documentos de la sociedad, como sus bases constitutivas, su reglamento o un proyecto de reconstitución, todos de 1845; los intereses del editor en este negocio se entienden a la luz de las innovaciones que introdujo en su establecimiento, para las cuales requería de coque y gas. Finalmente, la última sociedad que reunió a Boix con Fagoaga, en 1846, estaba ya directamente vinculada con el ramo de la imprenta y librería. Con ella nos adentramos en la última fase de su trayectoria.

\subsection{Nuevos proyectos, crisis diversas y últimos años (I846-I862)}

En verano de 1846 Boix se embarcó en un nuevo proyecto, la Sociedad LiterariaTipográfica de La Ilustración, que convocó a un grupo de banqueros, bolsistas, políticos y escritores - entre otros, Evaristo San Miguel, Pascual Madoz, José de la Revilla, el Conde de Tilly, Nazario Carriquiri y el propio Fagoaga - y que tuvo un capital social de 40 millones de reales. Boix desempeñó el cargo de director facultativo e inspector de todos los ramos de esta sociedad anónima dedicada a la compraventa de obras originales, así como a las traducciones extranjeras, la impresión, el estereotipado y la fabricación de papel. Dado que en sus primeros pasos la sociedad carecía de imprenta, se anunció la cesión de la de Boix, que en agosto ya asumió el nombre de la sociedad (BBEE, año vII,

28 La Caja de Ahorros se anuncia en mayo de 1843 y cuenta con un capital social de 75 millones de reales de vellón. Tenía sus oficinas en la calle Fuencarral, 53, donde repartían los prospectos, y contaba con comisionados en provincias ( $E N A, \mathrm{n}^{\circ}$ 232, 20-5-I843: I). En septiembre de 1844 comienzan a asegurar también los contratos de arrendamientos bajo el nombre de El Iris y en octubre, los contratos de préstamos (ENA, no 707, 22-IO-I844: 2). 
$\mathrm{n}^{\circ}$ I6, agosto I846: 256; $E C, \mathrm{n}^{\circ}$ I293, 20-I2-1846: I), al igual que su librería, que pasó a llamarse de la Ilustración (Diario de Madrid, $\mathrm{n}^{\circ}$ II7I, I7-I-I847: 3). ${ }^{29}$

En I847 la Sociedad Literaria-Tipográfica Universal de La Ilustración, con Fagoaga como uno de sus promotores, aglutinó las imprentas de Boix y de Madoz y Sagasti, todos directores de la sociedad (BBEE, año vII, nº I9, octubre 1846: 303 ). En realidad, tras este movimiento se ocultaba la situación que desde 1840 comprometía a Boix con Fagoaga, quien era un miembro destacado de su Junta de Gobierno. Así consta en una escritura de cesión y obligación con hipoteca que el editor y el banquero firmaron ante José de Celis Ruiz el 27 de septiembre de 1847 (AHPM, «Escritura de cesión...», Protocolos de D. José de Celis Ruiz, I847, leg. 25645, ff. IogI-I906). En ella Boix reconoce que no puede devolver a Fagoaga la enorme suma de dinero que le adeudaba y que, según la liquidación efectuada, ascendía a fecha de I de febrero de I846 a 4.690.272 reales de vellón, más otras cantidades posteriores, capital con el que desde 1840 había podido "plantear el establecimiento tipográfico que ha dirigido y llevado su nombre (...) destinándolas a la compra de obras originales, papel y demás necesario para realizar la infinidad de impresiones que se han ejecutado bajo su dirección, y a la de unos molinos de papel en Cuenca que habían de servir para completar dicho establecimiento». El 6 de noviembre del mismo año firmaron una escritura ante el mismo escribano para efectuar la liquidación (AHPM, «Escritura de cesión...», Protocolos de D. José de Celis Ruiz, i847, leg. 25645 , ff. I2I8-I232); en ella ya solo se declara la cesión de unas propiedades del editor en Cuenca —unos molinos y una fábrica de papel—..$^{\circ}$ Finalmente, el 6 de junio de I848 firmaron otra escritura de obligación en la que el editor hipotecó su patrimonio inmobiliario, que incluía en el momento las fincas madrileñas de Carretas, 27, Rejas, 4 y Molino de Viento, 5; una casa en Carabanchel de Arriba; una heredad en la villa de Onteniente «con unas heredades limítrofes y una casa de campo y otras pertenencias»; otra casa «en la calle de Onteniente, y una casa en la ciudad de Valencia». Así consta en el Archivo de Manuel de la Cortina, en el expediente de un pleito que entabló Boix en I853 contra los síndicos de la quiebra de Fagoaga sobre el reconocimiento de un crédito (AHICAM, Archivo de Manuel Cortina, 6I-43-IO47, I45-I46), cuando el banquero quebró, en el verano de i848. Por ello, esa última escritura entre el editor y el banquero de 6 de junio fue firmada en el momento más inoportuno para el editor ya que el 30 de junio, tras haber presentado Fagoaga su dimisión como director del Nuevo Banco de San Fernando, una comisión constituida de urgencia descubrió que este, haciendo uso de sus poderes para disponer de los valores del banco, había defraudado cantidades por valor de "4.800.000 reales, prácticamente en efectivo», más " 32 millones de reales en títulos del $3 \%$, y 29 millones en los del 5 \%» (Moreno, 2010: 83)..3

Boix trató de salir de tan apurada situación promoviendo otras empresas personales junto a sus hermanos y otros socios. Así nació en noviembre de i848 la sociedad en comandita A. Boix Hermano y Cía., registrada el i6 de ese mes, destinada al «comercio de libros españoles y extranjeros y edición de obras» e integrada por «D. Ignacio Boix por su hecho propio y en concepto de apoderado de su hermano D. Antonio, D. Andrés Boix, D. Antonio Ortigosa y D. Manuel Sorzano, todos vecinos de esta Corte». ${ }^{32}$ La sociedad, que

29 Su papel, por tanto, fue más allá del de mero editor de la sociedad, tal como apunta Martínez Martín (2018: I35).

30 Llegué a ambas escrituras a través de Otazu (1970: 325-327, 383).

3I Este capítulo entre el editor y el banquero merece, en todo caso, un estudio más detenido.

32 Registro Mercantil de Madrid [RMM], Registro general de cartas dotales, escrituras matrimoniales, escrituras de sociedad mercantil y poderes, con arreglo al artículo 22 del código mercantil, sancionado por $S$. M. en 30 de mayo de I829. Consta de cien hojas útiles rubricadas por el Excmo. Sr. Jefe Politico de esta Provincia D. Fermin de Arteta y Sesma, t. 2, asiento 874 , h. 33, I6-II-I848. 
se podría prolongar hasta cuatro años a contar desde el 22 septiembre, tenía a Boix como socio industrial y «director y gerente y único gestor», dada su experiencia y trayectoria, pero estaba a nombre de su hermano Antonio, quien aportaba el capital más elevado, y se mantuvo activa al menos hasta 1849 , con una imprenta en Tarragona y librerías en Carretas, 27 y Puerta del Sol, $4 \cdot^{33}$

En I85o empieza a asomar otra razón social, Boix, Mayor y Compañía, que incluía aún las librerías y una imprenta en Capellanes, ıo, pero que no sostuvo una gran producción; salieron de ella el periódico literario El Bardo y, sobre todo, devocionarios y otros libros religiosos. De este periodo data la única imagen conocida de Boix: se trata de una lámina litográfica estampada en 1849 en el establecimiento de Aragón — con el que Boix llevaba trabajando desde 1838 - que retrata a Boix posando de frente, en plano medio corto, engalanado con la cruz de Carlos III (Anónimo, i849). ${ }^{34}$

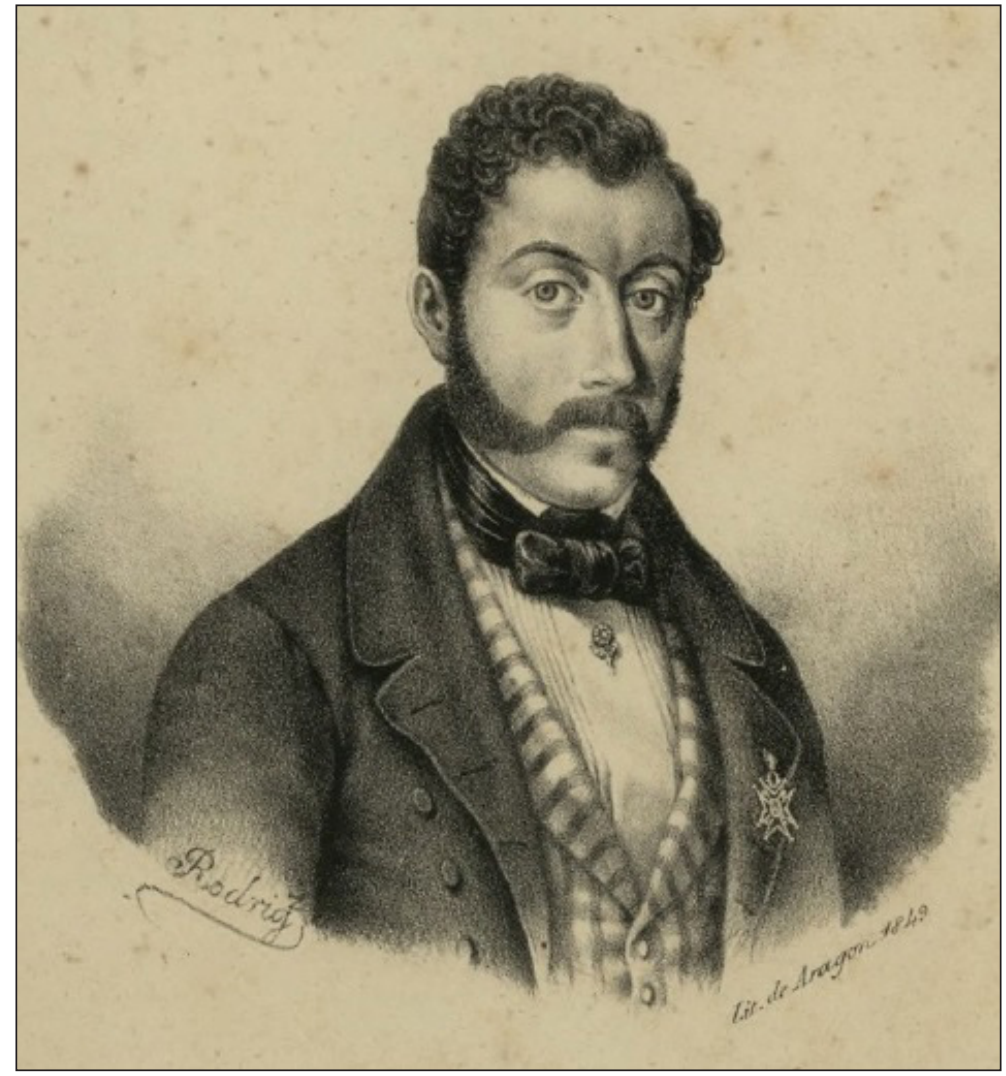

Retrato de Ignacio Boix y Blay (Anónimo, I849).

Fuente: Depósito Académico Digital Universidad de Navarra (DADUN)

33 No hay nota al margen de disolución de la compañía, pero las menciones en prensa a ella no van más allá de 1849. En cuanto al capital social, en la constitución de señala: «se compondrá por ahora de 300.000 reales vellón, Ioo.000 que pone D. Ignacio Boix como representante de su hermano D. Antonio, roo.ooo que pone D. Antonio Sorzano, 60.000 que también pone D. Andrés Boix y 40.00o D. Antonio Ortigosa, cuya total cantidad han ingresado en la Sociedad los citados socios, dándose mutuamente por entregados y satisfechos».

${ }_{34}$ En su periódico mensual El Bardo, que salió de la Imprenta de Boix Mayor y Compañía desde i85o, aparecieron retratos de características muy similares de Luis José Sartorius y Tapia, Conde de San Luis, o de Ros de Olano, entre otros; algunos también se debieron a Rodríguez y salieron del establecimiento de Aragón, como las pruebas del retrato de Maximiliano Sauli. 


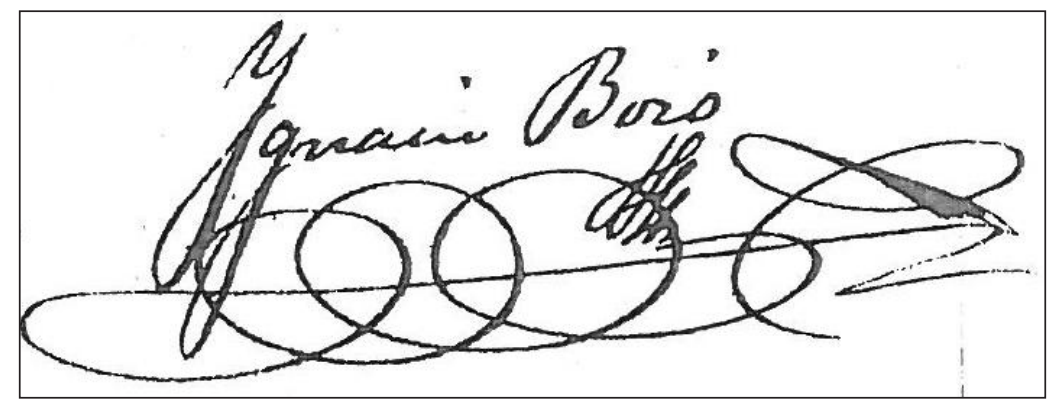

Firma de Ignacio Boix. Fuente: AHN (Consejos, leg. II.315, I20)

Los problemas económicos que arrastraba empujaron a Boix a buscar fortuna en París a finales de 1851, mientras que su hermano Andrés se estableció en México, donde fundó en 185r la casa Boix y Compañía Editores, un año después la casa Boix, Besserer y Compañía con el editor Carlos Besserer y ya en 1853 su propio negocio, el Establecimiento Tipográfico de Andrés Boix Editor, de corto recorrido (Peñas, 20I7f). ${ }^{35}$ En cuanto a Boix, se estableció en París como editor y librero y en solo tres años puso en marcha una ambiciosa sociedad editorial, La Madrileña (I85I-I852) para el comercio de la librería española en América del Norte y del Sur, aprovechando el posible acuerdo que España y Francia sobre propiedad literaria del que se estuvo hablando en noviembre de 185I. Esta sociedad, «para la circulación en grande escala y la propagación general de la librería española», tuvo un capital social de 500.000 francos divididos en 500 acciones de 1.000 francos cada una, como indica un temprano anuncio que incluye también el prospecto y recoge el apoyo que Donoso Cortés, entonces Encargado de Negocios de España en París, expresó por carta al editor a propósito de este proyecto $\left(C P, \mathrm{n}^{\circ} 23 \mathrm{I} 6,2 \mathrm{I}-\mathrm{I}-\mathrm{I} 85 \mathrm{I}\right.$ : 2-3). Boix abrió también una librería, la Librería Española y Americana (I85I); fundó la sociedad en comandita Boix y Cía., de la que era responsable junto al editor Apollon Lefèbvre, con quien trató también de impulsar una casa editorial, la Editorial Lefèbvre, propiedad de Boix y Cía. (1852) y, finalmente, un gabinete de lectura, el Gran Círculo Literario Hispanoamericano (1853).

Esta etapa francesa de Boix estuvo plagada de contrariedades. Su revista más ambiciosa, El Eco de Ambos Mundos (1852-1855), le generó múltiples problemas, desde una condena en abril de 1853 a dos meses de cárcel y 200 francos de multa por haberla publicado en Francia desde 1852 siendo extranjero y sin la debida autorización ni pago de fianza, así como por haber ejercido como librero ese mismo año sin permiso (JDPL, s. n., 6-6-I853: s. p.). ${ }^{36}$ También hubo de afrontar un juicio interpuesto por los editores de su principal competidor, El Correo de Ultramar (FJL, nº 12, I2-3-1853: 107-108), pero el golpe más duro para él fue la prohibición por parte del Gobierno español mediante una Real Orden de 23 de marzo de I852 de que sus periódicos impresos en Francia circularan en España y Ultramar (AHN, Consejos, leg. II.329, 93). Boix intentó por varios medios obtener permiso por el grave perjuicio que esa orden le causaba, pues tenía todas sus esperanzas de éxito puestas en su Eco y en el comercio con las Antillas. Así, el 28 marzo de 1852, Andrés Avelino de

35 Andrés, que se había casado en 1853 con Carlota Dongo, con la que tuvo tres hijos (Sanchiz y Gayol, en línea), murió el 4 de abril de 1858 a causa de una breve y aguda enfermedad ( $L S, 2^{\mathrm{a}}$ ép., I, no 95, 5-4-1858: 4).

36 Una carta fechada en París el I2 de agosto de I853 y dirigida desde el Ministerio de Asuntos Extranjeros al Marqués de Viluma, Ministro Plenipotenciario de España, revela que el 2 o de julio se había consultado al Ministro de Justicia para saber si un «Sr. Ignace Boix» español se había naturalizado francés; se responde que no se ha encontrado ningún acto de naturalización relativo a Boix en los archivos del Departamento de Justicia desde 1804 en adelante (AGA, ro, 95, Correspondencia con Ministerio y Autoridades francesas, no 658, I852-1853, s. 5.543). 
Orihuela, redactor del Eco y amigo de Boix, escribió a Juan Eugenio Hartzenbusch para pedirle su intercesión, convocando incluso la ayuda de personas cercanas al editor, como Gil y Zárate o Ferrer del Río. La carta tiene membrete de la librería de Boix en París y resulta muy explícita con respecto a la situación apurada del editor:

$\mathrm{V}$. es persona que me dispensa muy buena amistad, que tiene influencias respetables ahí, que conocerá todo lo grave del perjuicio que se infiere al amigo Boix, puesto que no hace más que comenzar una empresa a la que ha unido todos sus intereses y necesita apoyo y protección; por consiguiente créome autorizado por la bondad de su carácter para suplicarle el especial favor de que ponga en juego sus relaciones al logro del permiso solicitado, fundándose en que esta es una empresa puramente española, no es periódico de partidos ni banderías, en política una crónica de hechos (sic) y el gobierno ha permitido libre circulación a la empresa extranjera que sostiene el Correo de Ultramar periódico exactamente igual (Orihuela, [1852-I854]).

Tras la petición de Orihuela, Boix escribió de su puño y letra: «Sabe V. amigo don Eugenio que le aprecio y que necesito que tome en su mano este negocio; mándenos V. aquí lo que guste. Suyo. Boix». Un año más tarde, aún sin obtener la ansiada licencia, el editor, desesperado, dirigió a la reina una carta fechada a 22 de noviembre de 1853 (AHN, Ultramar, leg. 4640, 4) en la que empleaba argumentos similares a los que ya había esgrimido su redactor, pero su petición fue rechazada desde la Dirección General de Ultramar el I7 de diciembre. Poco antes, el 3 de noviembre, Boix ya había tenido que declarar en quiebra su sociedad en comandita con Lefebvre «Ignacio Boix et $\mathrm{C}^{\mathrm{a}_{\text {}}}$ (JDPL, s.n., 6-II-I853: 4) y acabó por vender el Eco a los hermanos Garnier (Zorrilla, I882b: 58). No obstante, la quiebra definitiva sobrevino cuando la casa Garnier interpuso a Boix una demanda por plagio del Diccionario de Salvá — del que tenía los derechos- en el Novísimo diccionario de Pedro Martínez López. Al margen del proceso que se dirimía en los tribunales, Boix se defendió en una «Advertencia del editor» estampada en el propio Novísimo y fechada el i5 de marzo de i854. Declaraba en ella que él se había limitado a encargar a Martínez López la corrección del Panléxico de Peñalver, obra que el editor ya había publicado en Madrid una década antes, para ofrecer una nueva edición corregida y aumentada como obsequio a los suscriptores de su Eco de Ambos Mundos; sin embargo, los hermanos Garnier le acusaron de plagio justo antes de publicar el libro, de modo que tuvo que suspender temporalmente su impresión — que le fue embargada - y afrontar un litigio con los editores franceses, tras cuya resolución positiva pudo imprimir la obra (Boix, 1854: s. p.). Sin embargo, este episodio hizo mucho daño al editor, como cuenta Martínez Villergas años después:

Para mí, lectores, quizá sea este el plagio de mayor trascendencia que cuenta la historia, debiéndose a él la ruina completa del citado Boix. Este perdió en la condena mencionada, no solo el desembolso que para la edición había hecho y la multa y la indemnización referidas, sino el abono de un año que esperaba de sus numerosos suscriptores pues habiéndoles ofrecido la prima del diccionario y no pudiendo cumplir lo prometido, pocos fueron los que se creyeron obligados a pagarle, y el resultado fue una quiebra en todo el rigor de la palabra ( $M M$, año IV, $\mathrm{n}^{\mathrm{o}} 48,30-8-\mathrm{I} 863: 380$ ). 
En I855 Boix todavía figuraba como librero en París (Bottin, I855: 88), pero debió de regresar a España poco después o en algún punto de 1856. Se estableció en Valencia, donde abrió un nuevo establecimiento tipográfico en la calle del Sagrario de Santa Cruz que bautizó con el significativo nombre de Imprenta de la Regeneración Tipográfica de Ignacio Boix y que inicialmente tuvo a Vicente Civera como regente, hasta I858 (Serrano, I898-I899: 73). En octubre de 1856 la imprenta ya estaba activa y dio la luz el periódico $E l$ Domingo, del que Boix era editor. A mediados de noviembre funcionaba también su taller de fundición de caracteres, ubicado en la Cruz Nueva. Durante estos últimos años Boix imprimió y editó un buen número de periódicos — la mayoría de efímera existencia- y procuró que su hijo Emilio se implicara en ellos. De hecho, consta que este desempeñó el cargo de secretario de redacción en al menos uno de ellos, El Eco de Valencia (LCA, n ${ }^{\circ}$ 355; I8-8-1859: 4); tenía entonces i9 años.

Todavía en su etapa valenciana Boix hubo de encarar reveses derivados de su etapa en Francia. En 1858 interpuso una demanda contra los editores Rosa y Bouret (Sirey, I863: 36-38) por reimprimir el Diccionario de sinónimos de Olive, obra para la que había efectuado un depósito en Francia en el año I852 y que pertenecía a su antiguo catálogo, pues la había editado en Madrid en $\mathrm{I} 843$. El fondo de la querella trataba de dirimir si el decreto de I8 marzo de 1852 que prohibía la falsificación en territorio francés de obras publicadas en el extranjero con depósito hecho en Francia se podía aplicar retroactivamente. ${ }^{37}$ Las resoluciones a sus recursos fueron negativas hasta la sentencia final de in de agosto de I862 que absolvió a Rosa y Bouret. Boix no llegó a conocer esta resolución, pues falleció cuatro meses antes.

Tras su muerte Ramón Álvarez, antiguo director de la fundición madrileña de Boix, adquirió todos los objetos del taller de la Cruz Nueva y con este fondo abrió una fundición propia que estuvo activa hasta I880 (Serrano, I898-1899: 174); la imprenta de Boix, en cambio, no tuvo continuidad y desapareció con el editor.

\section{Hitos de la producción tipográfica y editorial de Ignacio Boix}

Desde su rudimentaria imprenta con Matton hasta el establecimiento tipográfico de los años 40, pasando por las imprentas de Tarragona y Valencia, Boix dio a luz un enorme volumen de publicaciones de toda clase de temáticas entre libros, periódicos, revistas, obras de teatro, calendarios o partituras. No es el lugar para ensayar un cálculo aproximado de ellas ni para proponer una clasificación sistemática de las obras de fondo y las de surtido, los originales y las traducciones, los encargos y los proyectos editoriales propios; se deberá profundizar en otro lugar en ello, así como en las estrategias editoriales y empresariales de Boix y en su rol de mediador cultural, en el sentido que da Botrel al término a propósito de editores más conocidos como Mellado, Rivadeneyra o Ayguals de Izco (I997: 229-233)..$^{3}$ Nos limitaremos ahora a resaltar apresuradamente los títulos de especial relevancia para mostrar algunos de los principales hitos de la producción tipográfica y editorial de Boix. Antes, sin embargo, resultará interesante conocer el origen de esas producciones textuales y las condiciones materiales de su creación. Para ello, contamos con representaciones textuales y gráficas de su establecimiento que, además, contribuyen a reconstruir la actividad de la empresa tipográfica.

37 Sobre las ediciones fraudulentas y el monopolio de los editores franceses en el mercado del libro en castellano destinado a Latinoamérica, véase Fernández (r998).

38 Botrel expuso el caso de Boix para ejemplificar la dependencia de los editores españoles con respecto a las formas, modelos y géneros franceses (I997: 229-233) y apuntó tres títulos de su casa, si bien uno de ellos —Los animales pintados por ellos mismos - es de Mellado. 


\section{I. El establecimiento tipográfico de Boix en su plenitud: representaciones textuales y gráficas}

Entre I843 y I845 el establecimiento de Boix vivió su momento de máximo esplendor. Varios relatos periodísticos y documentos oficiales contienen información de interés al respecto no solo por la escasez de esta clase de fuentes descriptivas, sino porque ofrecen una imagen bastante precisa del valor técnico, tipográfico y económico de la casa Boix.

Se trata de cuatro testimonios complementarios. El primero procede de una publicación del propio Boix, El Laberinto. Es un artículo titulado «Tipografía. Reseña histórica del arte de la imprenta» firmado por J. G. Moya y que incluye tres grabados en madera donde se representan los espacios principales del establecimiento de Boix con una intención propagandística evidente:

Las tres vistas en perspectiva que se presentan con este artículo han sido tomadas con particular minuciosidad del establecimiento tipográfico del señor Boix, situado en la calle de las Rejas. La primera representa los grandes salones de cajas y despachos de los regentes. La segunda es un vasto local de prensas mecánicas modernas, máquinas de Stanhope y cilindros para lustrar y satinar, y la tercera son los almacenes de papel, alzador y tendederos. Este establecimiento es quizá uno de los mejores que existen en el día en España, de donde han salido millares de obras con hermosas impresiones, correcta y singular limpieza en los estampados de los grabados intercalados en sus textos, y suma delicadeza en la perfección de sus ediciones. Quisiéramos dar una noticia más extensa de su importancia, pero nos lo veda motivos de delicadeza a los que es fuerza someterse ( $E L, \mathrm{I}, \mathrm{n}^{\circ}$ 2, I6-II-I843: 24-26).

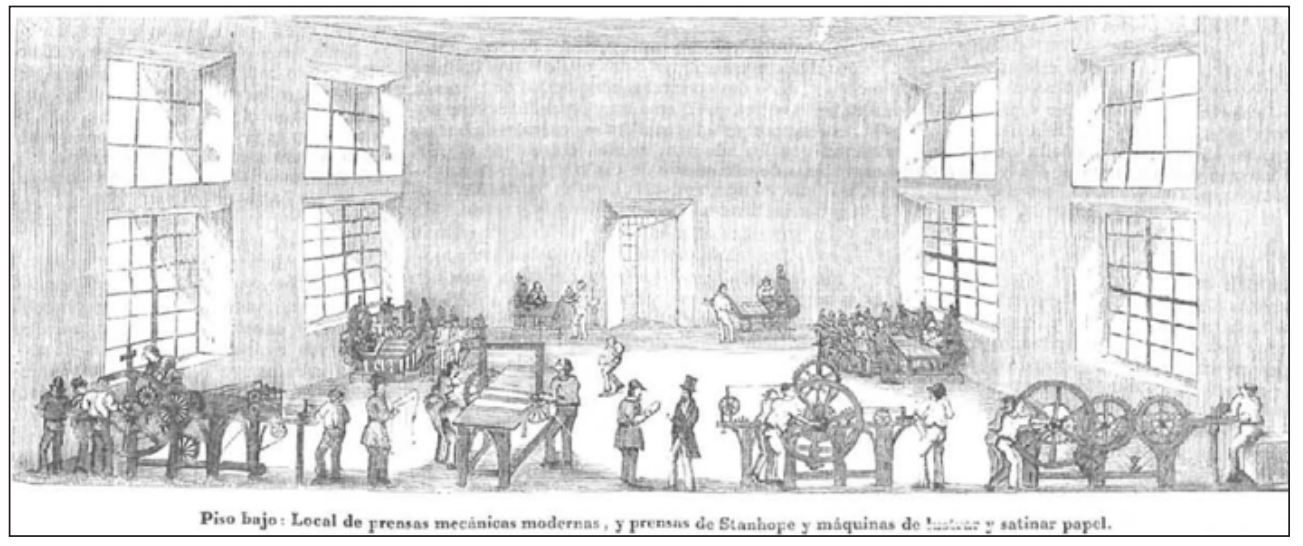




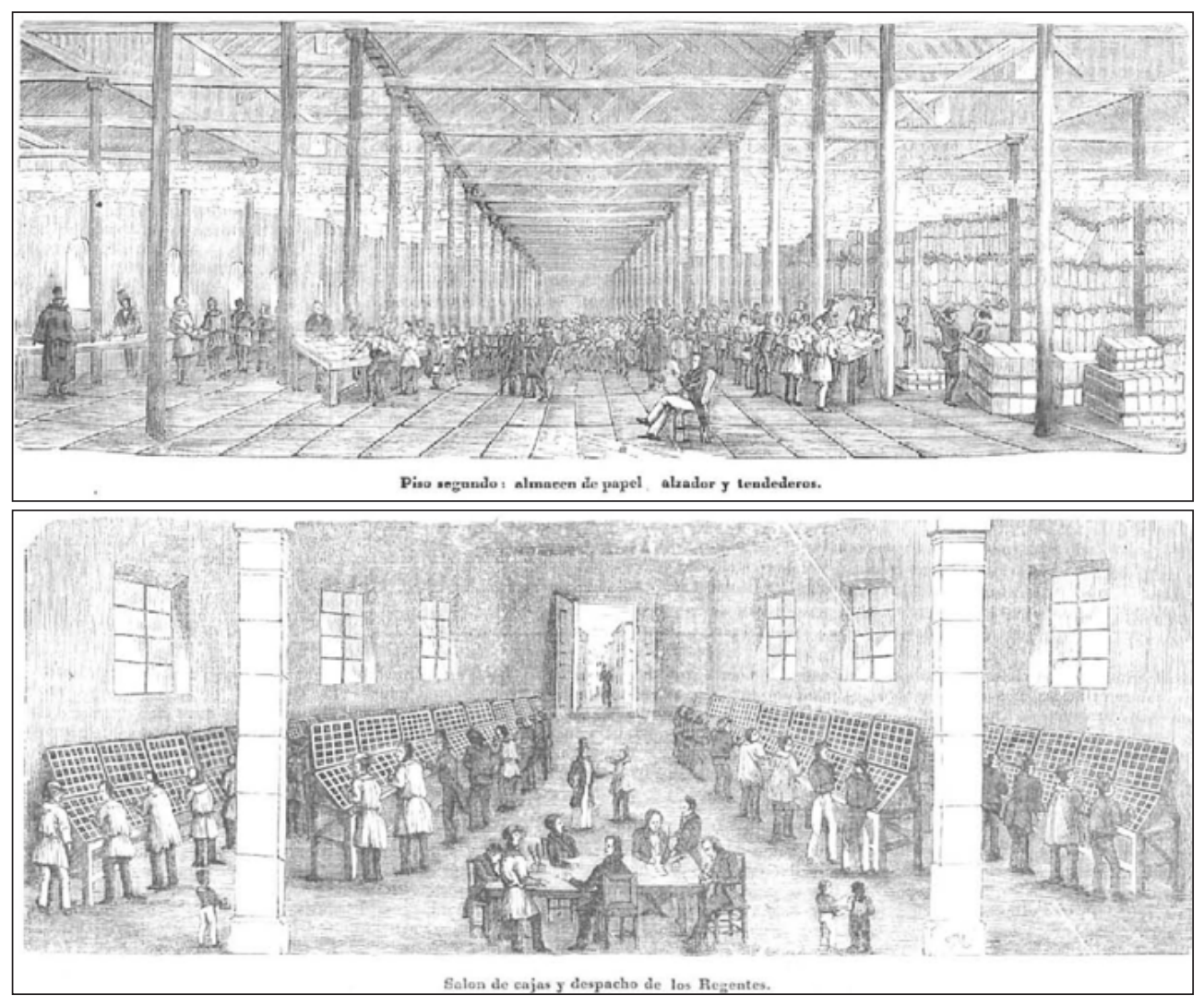

Vistas del Establecimiento Tipográfico de Ignacio Boix en Rejas, 4 (EL, I, no 2, I6-II-I843: 24-26). Fuente: Hemeroteca (BNE)

La segunda fuente es un informe emitido por una comisión de la Sociedad Económica Matritense de Amigos del País que, instigada por la belleza tipográfica de las obras de Boix — sobre todo, de su revista El Laberinto- y a invitación del propio editor y socio, visitó y examinó su imprenta en calle Rejas, 4, la «titulada del Diario de Madrid» (SEM, Sobre los establecimientos tipográficos de D. Ignacio Boix y premio que se le concedió, leg. 376/16). ${ }^{39}$ La Comisión, nombrada por la sección de Artes, estaba integrada por Juan Miguel de los Ríos, Juan Bautista Peyronnet, José Alejo Blázquez, Mariano Castellanos y Díaz, Antonio Martínez del Romero y Francisco de Michelena y Rojas. Este documento, redactado tres semanas después del artículo del Laberinto - $\mathrm{el}_{4}$ de diciembre de 1843 -, presenta abundantes datos descriptivos sobre el taller que amplían las escasas líneas del artículo anterior $\mathrm{y}$, sobre todo, evidencian las ambiciones de Boix, materializadas en dos proyectos que no llegaron a realizarse.

El relato comienza con los problemas de espacio del local, que, aun siendo grande y pudiendo «sostener doscientos operarios», resultaba pequeño para el volumen de negocio de Boix: «ni un rincón se halla desocupado». Las noticias que proporciona sobre la distribución del establecimiento coinciden con las que había dado el Laberinto, si bien las amplía y completa. Constaba de cuatro pisos: el bajo albergaba «hermosas prensas mecánicas, modernas máquinas de Stanhope y cilindros para lustrar y satinar»; en el

39 Recuérdese que Boix tuvo el privilegio de impresión del Diario de Avisos de Madrid o Diario de Madrid entre I84I y I847. 
principal había cajas de todas clases; el segundo piso acogía el almacén de papel; la buhardilla, finalmente, contenía los grandes depósitos de almacén de papel e impresiones. E1 informe también llama la atención sobre el fomento del comercio nacional por parte de Boix, pues «la mayor parte de los objetos son de fábricas nacionales», así como su «genio y patriotismo» que muestra tanto en sus producciones como en sus esfuerzos por «extender la circulación de ellas hasta en el extranjero, la importación (sic) de conocimientos de estos, trayendo maestros que enseñen los métodos modernos, no conocidos en España, generalizando la instrucción de su arte». Será este, por cierto, un argumento constante esgrimido tanto por el editor como por quienes le apoyaron y se apela, especialmente, al proteccionismo oficial al que necesitaba acogerse. El informe se hace eco de los borradores de un Manual de prensistas que Boix mostró a los miembros de la Comisión, así como de las propuestas que elevó al Gobierno para dirigir la Imprenta Nacional, por un lado, y para establecer una escuela normal de enseñanza completa de las artes de la imprenta — bajo su dirección - del grabado en madera, de la litografía y de la estereotipia, «cuyos discípulos más sobresalientes salgan de tiempo en tiempo a mejorar sus conocimientos y a importar del extranjero los nuevamente adquiridos», haciendo así más competente la industria tipográfica española para que recobrara «su comercio exclusivo con sus antiguas posesiones americanas independientes». Este fue el mismo objetivo que Boix adujo para establecerse en París y fundar La Madrileña ( $C P, \mathrm{n}^{\circ}$ 2316, 2I-I-I851: 2-3). Finalmente, dados sus esfuerzos industriales y patrióticos, la Comisión solicitaba que la Sociedad concediera al editor el uso de su escudo en sus establecimientos tipográficos, así como ayuda para estimular la publicación de su proyectado manual técnico y la recomendación de sus proyectos al Gobierno. Todo ello fue aceptado por la Sociedad tras varias juntas ${ }^{40}$ y Boix empezó a estampar a partir de I844 en sus publicaciones el escudo de la Sociedad, que también colocó en la puerta de su establecimiento ( $A P, \mathrm{I}, \mathrm{n}^{\circ}$ 3, I-9-1844: 399).

El tercer testimonio ofrece ya una imagen del nuevo establecimiento de Boix en la calle Alameda. Es una crónica anónima que apareció en El Clamor Público en junio de I844:

Hemos visitado el establecimiento tipográfico de don Ignacio Boix situado en la platería de Martínez donde estuvo el Cisne. Consta de cuatro espaciosos salones; en uno de los del piso bajo se hallan las prensas de hierro, tres hermosas máquinas con las que se tiran de cinco a seis mil pliegos por hora, máquinas para satinar y lustrar papel y un tórculo para tirar láminas finas; en el otro salón del piso bajo está el almacén de papel blanco que contiene cinco mil resmas de todas clases y tamaños; se ven en el piso principal, las cajas donde pueden trabajar con holgura ciento y cincuenta (sic) operarios; en el piso segundo está el alce y el almacén de papel impreso. Todas las dependencias del establecimiento están montadas con el mismo orden y perfectamente divididos el despacho del administrador y el del regente y correctores. Dentro de pocas semanas las máquinas del señor Boix serán movidas por el vapor, agente el más poderoso de la industria, e iluminado por el gas todo el establecimiento. No podemos menos de elogiar la actividad, inteligencia y perseverancia de un particular que fiado en sus propias fuerzas ha conseguido a costa de afanes dar impulso a la industria tipográfica y a la literatura con el prodigioso número de obras que ha publicado en pocos años. Cuantos han visitado el estable-

40 Únicamente se acordó, a propósito de la recomendación de los proyectos de Boix al Gobierno, la supresión de la mención a «otros [proyectos] que le tiene presentados en beneficio del erario público y de las mejoras en los ramos de imprenta y sus agregados». Todo el proceso quedó registrado en las páginas del periódico de la SEM; el informe también se reprodujo íntegro $\left(A P, \mathrm{I}, \mathrm{n}^{\mathrm{o}} 3, \mathrm{I}-4-\mathrm{I} 844: 76-78\right)$. 
cimiento nuevamente planteado por el señor Boix hacen de su celo y laboriosidad elogios iguales a los que nosotros le tributamos; celo y laboriosidad que proporcionan el sustento a más de trescientas familias $\left(C P, \mathrm{n}^{\circ} 37, \mathrm{I} 2-6-\mathrm{I} 844: 4\right)$.

De esta noticia resaltan datos como la capacidad de la maquinaria de Boix, la amplitud del nuevo enclave y la introducción de dos avances significativos, el vapor y la iluminación por gas, mejoras todas que la Sociedad Económica Matritense llegó a atribuir al premio que había concedido al editor tras la primera visita a su establecimiento $\left(A P, \mathrm{I}, \mathrm{n}^{\circ} 3, \mathrm{I}^{-} 9^{-}\right.$ I844: 399).

La última fuente en este repaso cronológico procede del mismo expediente de la Sociedad Económica Matritense antes citado (SEM, Sobre los establecimientos..., leg. 376/r6). En este caso, José Alejo Blázquez y Nicolás Casas solicitaron a la Sección de Artes en un escrito de 2 de abril de 1845 que otra comisión inspeccionara el nuevo establecimiento de Boix de la calle Alameda para determinar si la Sociedad podía «alentar a tan infatigable artista». La propuesta se sostuvo con argumentos que repetían los adelantos artísticos y tipográficos de Boix ya señalados por la comisión de 1843, añadiendo sus últimos progresos, que justificaban, según la comisión, el apoyo al editor. Resaltaron, así, «las grandes mejoras que nuestro consocio D. Ignacio Boix ha hecho en sus establecimientos»; el hecho de «haber sido el primero que entre otras cosas ha puesto en España su imprenta movida e iluminada por el gas carburo hídrico o producto del carbón de piedra, haciendo para esto venir las maquinarias del extranjero, y dando animación al comercio del carbón mineral»; asimismo, apuntaron «el sinnúmero de obras originales» que daba a luz y la rapidez con que traducía las extranjeras, "proporcionando vida a nuestra literatura y alentando (...) a los hombres estudiosos de todas las carreras», insistiendo, en fin, en la contribución de Boix a la literatura, las artes y el comercio «a costa de los mayores sacrificios de todos conocidos». La propuesta se admitió en una junta de ese mismo 2 de abril de I845; esta Comisión, que quedó integrada por Santiago Piñeiro, José Segundo Flórez, Joaquín Núñez de Prado y el propio José Alejo Blázquez, efectuó la visita el día 4 de abril en compañía de Boix, como en la ocasión anterior, y se emitió un informe fechado el día 20 .

Este segundo informe, de nuevo muy detallado, comienza destacando la notable mejora de este establecimiento con respecto al anterior de Rejas y celebrando que Boix haya logrado un «local más espacioso», «uno de los pocos a propósito que hay en la Corte»:

En el piso bajo de este grandioso edificio, a la derecha de la entrada principal, hay un inmenso salón donde una balaustrada separa las varias prensas de mano a la Stanhope de las mecánicas, de las cuales tres están movidas por el vapor y las otras dos a brazo: encima de cada máquina cabe una lámpara iluminada por el gas. Al pie de este salón están en una pieza reposada los aparatos que dan movimiento y luz aparte del establecimiento. Estas máquinas no se las puede considerar sino como un lujo con el que el Sr. Boix ha querido hermosear su establecimiento, y aquí está bien cuente sin comentarios de ninguna clase lo que ha oído decir a varios operarios. Cuando el dueño de esta fábrica quiso mover por medio del vapor la maquinaria, en atención al ahorro considerable que le ocasionaba, se presentaron a él las familias de una porción de jornaleros, manifestándole que con este adelanto dejaba en la miseria a sus padres, a sus maridos y a sus hijos, a lo que contestó: «prefiero ganar menos que causar la ruina de ninguna familia; ya no mandaré a pedir más que una máquina pequeña que solo pueda mover una o dos prensas». Honra tanto este hecho al Sr. 
Boix, poco conforme sin embargo, con los buenos principios económicos, que no ha querido la Comisión pasarlo en silencio, mucho más después de haber sentido las lágrimas en los ojos al ver el agradecimiento de los infelices que hubieran sido despedidos.

El aparato del gas aumentado en Madrid por un español funciona bien y es muy capaz para iluminar a todo el establecimiento.

Siguiendo el camino que en medio del salón deja la doble balaustrada, se va a una escalera colgada que comunica con el piso principal, dejando a la derecha la dependencia del lavabo del papel y de la letra. Desde el primer descanso de esta escalera se ve toda la hermosura, toda la animación de este departamento, que si no es el que contiene más riqueza, llama mucho la atención por verse en él representadas las dos invenciones más grandes del hombre, la prensa y el vapor.

En el piso principal están colocadas las cajas en varios salones con todas sus dependencias, corrección de pruebas, depósito de clichés, despacho de los regentes, las oficinas de contabilidad y un gabinete para el dueño y para los escritores. E1 silencio de este departamento contrasta singularmente con el ruido uniforme y continuada que hay en el de abajo, no obstante de haber en él unos I2o veinte cajistas.

En el salón principal del piso segundo una balaustrada divide como en el bajo unas operaciones de otras. A la izquierda de la escalera que conduce a este piso está el taller de carpintería en pieza separada. Entrando en el gran salón a la izquierda se ven los hornos de la fundición de letra en un departamento; en otro la estereotipia; en otro mujeres y chicos limpiando letra; a la derecha las máquinas de satinar y las de litografiar recibidas recientemente; más allá el departamento de plegado, encuadernación y colgaderos. En la cabecera de este salón hay varias piezas donde están el despacho del administrador y los encargados de la parte económica de los periódicos; a los pies están los depósitos de matrices y metales y una pieza para el director y demás operarios de impresión de la música, mejora que el Sr. Boix ha introducido en España donde tanto se hacía sentir su falta y que va a ver la luz muy breve (sic) por tener ya todos los punzones abiertos.

Los almacenes de papel ocupan ocho piezas, sin que haya en ellos nada desocupado, en pilas inmensas de quinientas y seiscientas resmas de todas las fábricas de España, y de todas las clases y dimensiones.

El depósito de obras impresas bien puede suponerse lo que es al ver el catálogo de las publicadas por la Casa.

La Comisión visita acompañada del Sr. Boix los despachos de librería que tiene en la calle de Carretas en el número 8 el antiguo y número 35 el moderno en el que ha visto realizados sus deseos en este ramo el más importante quizá de la riqueza de las naciones: aquí se ve un ejemplar puesto al alcance de la fortuna más pequeña junto a otro encuadernado junto a un lujo y primor artístico tal, que solo las personas más acomodadas de la sociedad pueden adquirirlo (SEM, Sobre los establecimientos..., leg. 376/I6).

El informe continúa resaltando los avances industriales y artísticos de Boix: la extensión del «comercio de nuestra literatura» y «el progreso (...) que de pocos años han revivido todos los ramos de literatura», pero también «el grabado en madera», que «también le debe mucho, y la litografía de colores y de realce, y la impresión de la música, cualquiera que sea su escrito, recordarán al Sr. Boix como su introductor en España». En cuanto a los «productos de las diferentes fabricaciones y máquinas», comprenden "papel, 
letra fundida, libros, encuadernaciones, planchas de estereotipia, litografías de colores y de realce, música impresa, coque y carburo hídrico», lo que evidencia los intereses de Boix y explica su participación en Sociedad Palentina-Leonesa de Minas o sus esfuerzos por impulsar un establecimiento tipográfico musical. $4^{1}$

Tras unas consideraciones sobre el papel y el abaratamiento de costes necesario para competir con otros países en el comercio de libros — con alusión, de nuevo, al mercado de Ultramar- y sobre las matrices de fundición, cuya variedad se apreciaba en su catálogo de caracteres (Boix, 1845), el informe concluía con un repaso de los méritos de Boix como editor:

Este dictamen sería interminable si la Comisión fuera a especificar uno por uno los beneficios que el Sr. Boix tiene hechos al país; para esto basta ver el catálogo de obras originales de que es propietario. Pocos o ninguno de los hombres que se distinguen cultivando las ciencias, las artes o la bella literatura han dejado de encontrar en el ánimo infatigable del Sr. Boix un apoyo en sus estudios y en sus investigaciones y una salida cómoda a sus obras. Es curioso ver fijados en la pared del salón de prensas por la costumbre de los operarios tantos retratos, tantas viñetas, tantos países que representan a otros tantos autores y a otras tantas obras de artistas originales que hacen una prueba de lo que hemos sentado; también allí entre otras se ve la vigorosa cabeza de nuestro tierno e inolvidable amigo José Espronceda.

Dispénsenos la sección si recordamos haber visto en el secreto de nuestras relaciones al autor del Diablo mundo decidido a romper este magnífico poema del que se ha dicho que su autor «se levanta en él con la osadía del genio para escalar a donde nadie se ha atrevido a mirar de hito en hito sin confundirse», por no encontrar persona que quisiera publicarlo y después de esto ¿puede juzgarse al Sr. Boix como un simple librero? Ciertamente que no. La posteridad ha prodigado merecidas alabanzas al mecenas del Tasso, el nombre de Augusto va unido a la gloria de Virgilio, la generosidad del Duque de Béjar reclama una parte en la ovación universal concedida a la obra eterna del herido de Lepanto (SEM, Sobre los establecimientos..., leg. 376/I6).

Esta descripción no solo tiene el valor de mostrar datos sobre el funcionamiento del establecimiento tipográfico de Boix que permiten apreciar su envergadura y modernidad. También ofrece el testimonio de la preocupación de los obreros ante los adelantos técnicos que asumía progresivamente la industria — representada en el relato mediante una escena dramática — o la participación de los agentes más invisibles del oficio, mujeres y niños, así como un retrato plástico y sensorial de la decoración, los objetos y el ambiente que se vivía en el taller.

En cuanto a la estructura y volumen de la empresa de Boix en estos años, resulta capital una nota manuscrita sin firma que acompaña al expediente de visita y que, a pesar de no llevar título ni aclaración alguna, es un listado de los trabajadores del establecimiento que un miembro de la Comisión anotó durante la visita de I845. En él se apuntan 6 conductores de máquinas y 16 prensistas; 40 mozos; I20 cajistas en casa — tal como consta en el informe-, más otros 40 fuera, «en otras varias imprentas»; 20 autores originales y 30 traductores; 8 dibujantes; I6 grabadores; I2 litógrafos y dibujantes; 24 encuadernadores de

4I Para ello firmó un contrato de tres años con «el señor López, inventor (...) de la tipografía musical», que acababa de obtener el privilegio de invención para España y Francia por diez años; en esta asociación, el empresario ponía «su capital» y López, «su industria» $\left(L P, \mathrm{n}^{\circ} 784\right.$, 30-8-1844: 4; $E L, \mathrm{I}, \mathrm{n}^{\mathrm{o}}$ 2I, I-I-I844: 293). 
obra fina y otros 20 para rústica y plegado de entregas; 4 mujeres para coser libros y otras 4 «que hacen patrones»; 8 dependientes para los despachos; I4 escribientes; 2 regentes y, finalmente, 2 administradores, «uno del establecimiento y otro de periódicos» (SEM, Sobre los establecimientos..., leg. 376/r6). Es decir, en total, Boix tenía empleadas a 386 personas, cifra que da medida del volumen de trabajo que llegó a tener su establecimiento, sobre todo si se compara con el de Mellado, quien dos años más tarde, en 1847, tenía casi dos veces menos personal que Boix. ${ }^{42}$

A la luz de todo lo expuesto, los miembros de la Comisión solicitaban al final de su escrito tres reconocimientos para Boix: el título de socio libre de contribución, el uso del timbre de la Sociedad en todas las obras de su imprenta y la publicación del propio dictamen. Salvo el último, todos tuvieron efecto: fue nombrado socio libre de cargas y se le autorizó para usar el escudo de la sociedad en todas las obras de su imprenta. ${ }^{43}$

Algunos de los integrantes de las dos comisiones de 1843 y I844 que emitieron estos informes apologéticos tenían, si no amistad, sí relación previa con Boix, lo que sin duda influyó en el respaldo que dieron al editor. ${ }^{44}$ Ello, en todo caso, no resta veracidad a los documentos, que contienen datos contrastables en otras fuentes. ${ }^{45}$ Son representaciones textuales y gráficas circunscritas únicamente a los años 1843-1845, pero que, en todo caso, revelan una imagen nítida del estadio de mayor sofisticación editorial y tipográfica que alcanzó la Casa Boix.

\section{I Los libros}

Los catálogos de librería son una herramienta esencial para ofrecer algunas cifras provisionales de los libros que Boix publicó. De los años 30 contamos con dos listados, pero corresponden a su etapa inicial como librero y solo dan una medida aproximada del volumen de libros que tuvo a la venta. En el primero se incluyen 85 títulos; en el segundo ya hay I43 (Matton y Boix, 1830, 1831).

La profesionalización del editor a finales de esa década y comienzos de la siguiente conlleva un aumento de los catálogos, pero han de tomarse con cautela por su información a menudo poco exacta e incompleta. En 1840 Boix contaba con 56 obras de fondo «propias» (Boix, I840), si bien no todas salieron de su imprenta; ${ }^{46}$ además, a menudo se incluían solo las obras que interesaba publicitar, en función de diferentes criterios como la temática del libro donde se estampaba el catálogo o la nueva colección que interesara vender.

42 Citando a Madoz, López Zazo recoge estas cifras: «Respecto al personal que trabajaba para él, en I847 se ocupaban en el Establecimiento Tipográfico I2I operarios. De estos, 42 eran cajistas, 23 prensistas, maquinistas y mozos, 7 se ocupaban en los almacenes y alzadores, y 13 trabajaban en el taller de encuadernación. En labores de administración, contaduría y distribución Mellado ocupaba a I3 empleados, a I5 en el despacho de Madrid (incluidos repartidores) y a 6 redactores» (2010: 59). En un documento escrito por Mellado en agosto de I848, en cambio, el propio editor indica que sostiene a más de doscientas familias (en Martínez Martín, 2018: 308).

$43 \mathrm{El}$ uso del escudo generó una polémica posterior que se recoge en el informe.

44 Es el caso de Francisco Michelena y Rojas, cuyos Viajes cientificos (I843) salieron de su imprenta el mismo año en que participó en la comisión o de Juan Miguel de los Ríos, quien había colaborado con Boix años atrás (Boletín de instrucción pública, I838) y volvería a hacerlo poco después (Código español del reinado intruso de José Napoleón Bonaparte, o sea colección de sus más importantes leyes, decretos e instituciones, I845). Por su parte, José Segundo Flórez fue director y redactor en jefe del El Eco de Ambos Mundos de Boix en París, cargo al que renunció con el resto de la plantilla por disensiones con la administración ( $C P, \mathrm{n}^{\circ}$ 2850, 29-10-1853: $\left.\mathrm{I}\right)$.

45 Entre esas fuentes están, precisamente, el artículo del Laberinto y el que a continuación se aduce.

46 A este propósito, Salvá señala: «Hablando de los libros que tiene de venta un librero, se entienden como de su fondo los que ha impreso de su cuenta, o de que ha adquirido un considerable número de ejemplares, a diferencia de los otros que se llaman de surtido» (I846: 525 ). 
El listado más completo y sistemático de las obras de Boix que se conserva es el Catálogo general de los libros de fondo de la Sociedad de la Ilustración (Sociedad, I847), sociedad que, como se vio, asumió los fondos del editor; la «Advertencia» inicial apunta, de hecho: «Este catálogo anula los del señor Bois (sic)»). En él se recogen 227 títulos impresos en 335 tomos de libros de fondo. ${ }^{47}$ Las colecciones se presentan por separado: el Tesoro de las Ciencias Médicas consta de Ir títulos repartidos en 27 tomos, más otros 9 en prensa que se publican por suscripción proyectados en 48 tomos (de los cuales ya iban impresos I9); 1a Biblioteca de Obras Homeopáticas tiene 7 títulos proyectados en 8 tomos, de los cuales habían salido 5 títulos en otros tantos tomos; finalmente, la Colección Económica de Novelas Españolas y las Mejores Extranjeras de Autores Acreditados, con 8 títulos en $5 \mathrm{I}$ tomos. De «Obras recientemente impresas», sin mayor distinción, se consignan $\mathrm{I}_{4}$ títulos en 3I tomos, mientras que de «Obras modernas que se están publicando por suscripción» hay I7 títulos en 58 tomos. Finalmente, el catálogo presenta I3 títulos en 24 tomos de «Obras que hay dispuestas para entrar en prensa», así como un listado de 64 Comedias Modernas cuya «propiedad de impresión y representación en los teatros es de la Casa de Boix» — más tarde pasarían a Lalama-.

El total asciende a la considerable cifra de 355 obras en 553 tomos, una producción que abarca quince años de labor editorial, desde las primeras impresiones de Boix con Matton en 1832 hasta el momento de publicación del catálogo. ${ }^{8}$ En un estudio más detenido sería preciso analizar el volumen de la producción de Boix, tanto el potencial —con información sobre la maquinaria de que disponía—, ${ }^{49}$ como el real, teniendo presentes los datos dispersos disponibles de ventas y tiradas - especialmente significativas en el caso de algunos éxitos como el Panléxico, del que se agotó la tirada de 1o.ooo ejemplares-. De la última etapa en París y Valencia, en cambio, disponemos de menos datos. Los anuncios en prensa sobre su actividad en Francia señalan, por ejemplo, que su nueva librería «comprende ya las obras de más de 3.000 autores» ( $L E$, año 6, no 1542, IO-4-1853: 4); en todo caso, sería necesario estudiarla de forma independiente, pues respondía a una estrategia editorial completamente nueva.

De entre los títulos más relevantes para la historia de la literatura que Boix editó e imprimió en su casa hay que destacar algunos como El diablo mundo de Espronceda, con introducción crítica de Ros de Olano, que Boix sacó con un retrato del autor por entregas a finales de julio de 1840 y en libro en I84r; las poesías de unos jóvenes Miguel Agustín Príncipe y Antonio García Gutiérrez (1840); los Cantos del trovador de Zorrilla (1840-184I) y sus Vigilias del estio (1842) o Los españoles pintados por sí mismos (I843-1844), un clásico de las colecciones costumbristas. De hecho, Boix contribuyó, más que ningún otro editor, a la difusión del imaginario costumbrista y de la literatura ilustrada no solo con este título tan emblemático, sino también con otros como Los niños pintados por ellos (sic) mismos (I84I); los Trabajos y miserias de la vida (1842) de Andueza; la cuarta edición de las Escenas matritenses (1845) de Mesonero Romanos, en edición profusamente ilustrada y con introducción crítica de Juan Eugenio Hartzenbusch; Los ingleses tales (sic) como son (1858) de Tomás Bertrán Soler o Los valencianos pintados por sí mismos (I859), que publicó tres años antes de morir y con el que intentaba replicar el modelo de los Españoles, tan exitoso en los años 40.

47 Algunos se imprimieron en formato pliego, otros en cuadernos, pero se simplifica con el formato más común.

48 En el total de tomos solo se incluyen los impresos, no lo proyectados; tampoco se incluyen las 88 entregas que aparecen dentro de las obras modernas por suscripción.

49 Así, por ejemplo, en 1843 un periódico señalaba que Boix «puede dar un servicio de cuatro o cinco mil ejemplares de cualquier obra por hora (...) así no es extraño que todos los años se aumente considerablemente el catálogo de sus ediciones» (EC, 2 $2^{\mathrm{a}}$ ép., no 216, 4-4-1843: 3). 
De su etapa parisina sobresale su edición de La cabaña del tío Tom (1852), traducida por Andrés Avelino de Orihuela; fue la primera versión al castellano de esta obra de Harriet Beecher Stowe, casi al tiempo que en Madrid se vendía la de Ayguals de Izco (Gifra, 2006: 220). De su última etapa valenciana destacan sus ediciones de las poesías de José Bernat Baldoví y la ya citada colección de los Valencianos, ambas de I859 (Peñas, 20I7d).

Boix no solo se centró en literatura: también dio a luz títulos notables de jurisprudencia, crítica, historia y política; a su muerte, Antonio Ferrer del Río recordaba algunos de los más destacados:

A luz dio obras tan importantes como la Recopilación de las leyes de Indias; el Febrero reformado por los señores Montalbán y Aguirre, y posteriormente por el Sr. García Goyena; las Alegaciones fiscales de Campomanes bajo la dirección del ministro de Gracia y Justicia D. José María Alonso; varios tomos de biografías de contemporáneos escritas por muy acreditadas plumas; (...) la Historia del Consulado y del Imperio (...) ( $L A C H$, año vI, $\mathrm{n}^{\circ}$ 4, 24-4-1862: 16).

Cabe añadir que Boix editó las Lecciones de derecho politico constitucional dictadas por Antonio Alcalá Galiano en el Ateneo en el curso 1843/1844 — taquigrafiadas por dos colaboradores del editor, el propio Ferrer del Río y Juan Pérez Calvo-, al igual que las lecciones de derecho penal de Joaquín Francisco Pacheco. Asimismo, dio a luz diccionarios muy populares como el Panléxico de Peñalver, el Diccionario de sinónimos de Olive o el Nuevo diccionario de agricultura de François Rozier, en 13 tomos y con más de cien láminas - para el que contó con el mismo traductor de la primera edición, el político y agrónomo Juan Álvarez Guerra-, entre otras herramientas lexicográficas técnicas.

La historia y la política ocuparon un lugar privilegiado en las publicaciones de Boix a lo largo de su carrera. Así, editó títulos destacados la historia de la Guerra de la Independencia, del liberalismo, del carlismo y del memorialismo como El General Rodil; la Fisonomía moral y política de los procuradores de las Cortes de 1834, 1835 y I836, por un asistente diario a las tribunas de Fermín Caballero; las Memorias contemporáneas de Carnerero; los Ecos de Navarra o Don Carlos y Zumalacárregui de Ducasse; la Historia de la Guerra de la Independencia por una Sociedad de Literatos; la Muerte del Conde de España y biografía del cura Merino - con un prólogo anónimo probablemente del mismo Boix-; las Memorias documentadas del teniente general Manuel Llauder, la Biografía contemporánea universal y colección de retratos de todos los personajes célebres de nuestros dias; la Galería de hombres célebres contemporáneos de Cárdenas y Pastor Díaz; los Fastos españoles o efemérides de la guerra civil, desde octubre de I832 hasta el día y la traducción a cargo de Ramón de Navarrete de Napoleón y sus contemporáneos de Chambure — que Boix dedicó personalmente a Espartero y cuyas entregas no por casualidad comenzaron a repartirse apenas dos meses después de que el Partido Progresista ganara las elecciones a Cortes-, entre, en fin, otras muchas obras y panfletos políticos de liberales moderados y progresistas que dan la medida de la producción de Boix en este ámbito.

\subsection{Las colecciones}

Boix entró en el mercado de las colecciones de la mano del teatro, donde vio un claro negocio. Siguiendo el ejemplo de la exitosa Galería Dramática que puso en marcha en 1835 el editor Manuel Delgado, Boix lanzó en I839 su propia colección, que se prolongó hasta 1843: el Repertorio Dramático, o «Colección de las mejores obras del teatro moderno extranjero y moderno español». Su lanzamiento se anunció el 7 de abril en la 
revista teatral El Entreacto, de la que Boix era editor propietario, y quedó inaugurada a mediados de mes con El cómico de la lengua de Bayard, traducido por Juan del Peral. Boix ofrecía los prospectos de las obras en su librería de Carretas y las imprimía en dos formatos: en piezas sueltas y tamaño casi de folio y, a la vez, en formato más pequeño y tomos numerados con cinco o seis títulos, pues aprovechaba como plataforma de difusión el periódico: ofrecía un drama o comedia en el tamaño de El Entreacto y después la imprimía aparte en octavo (Cotarelo, 1928: I24).

La competencia que Boix presentó a Delgado enfrentó rápidamente a ambos editores, ${ }^{50}$ aunque en junio de I839 llegaron a un acuerdo para imprimir las obras con idéntico formato. El anuncio de esta alianza tiene interés, además, porque revela los nombres de los escritores que dirigieron ambas colecciones:

Parece que don Manuel Delgado, y don Ignacio Boix, dejando rivalidades que solo contribuirían al perjuicio de la literatura, se han decidido a dar las comedias del teatro antiguo español empezando el primero por las de fray Gabriel Téllez - conocido generalmente por el maestro Tirso de Molina - y el segundo por las de don Agustín Moreto. Los nombres de don Juan Hartzenbusch y don Gerónimo de la Escosura, a cuyo cargo está la publicación de estas colecciones, es suficiente garantía del acierto en la elección de comedias. No podemos menos de elogiar la idea de los editores al ejecutar la publicación en iguales tamaños y caracteres de letra, pues este modo se facilita al público el poder reunir en una ambas colecciones $\left(E E, \mathrm{n}^{\circ}\right.$ 24, 20-6-1839: 96$)$.

A finales de I84I Joaquín Merás lanzó su Museo Dramático, que alcanzó hasta I844, cuando fue adquirido por el impresor y editor Vicente Lalama para su Biblioteca Dramática (Cotarelo, 1928: 126), quien compró también la propiedad del Repertorio de Boix poco antes de que este se marchara a París debido a sus apuros económicos:

El editor D. Vicente de Lalama acaba de adquirir la propiedad de la Galería que pertenecía a don Ignacio Boix, así como hace un año también adquirió la que con el título de Museo Dramático publicaba en esta corte don Joaquín Merás. Es de alabar el celo de este editor: pues en cinco años que lleva de vida su Biblioteca dramática, cuenta esta con más de quinientas propiedades, colección de comedias la más numerosa después de la de Delgado, a la que muy en breve superará en número. Las empresas de provincia tienen en ella un buen repertorio donde escoger producciones representadas con grande aplauso en todos los teatros del reino ( $L N$, $\left.\mathrm{n}^{\mathrm{o}} 354, \mathrm{I} 8-6-1850: 3\right) .^{.5}$

Lalama «reimprimió varias de las obras de Boix, que por ello fueron algo más conocidas y representadas» (Cotarelo, I928: 125). En total, el Repertorio Dramático de Boix que pasó a manos de Lalama constó al menos de 64 títulos (Sociedad, 1847).

50 Los enfrentamientos entre editores por ganarse un hueco en el mercado editorial fueron muy frecuentes y, en este sentido, Boix no fue una excepción y mantuvo polémicas con Calleja, Merás, Delgado, Garnier o Rosa y Bouret. Se trata de episodios que merecen un estudio independiente.

5I Hidalgo se hace eco de la noticia dos días antes y apunta: «después de la Galería de los herederos del señor Delgado, puede asegurarse que esta colección es la más numerosa y selecta que se conoce, pues en ella no solo se encuentran obras originales de los principales autores sino también la mayor parte los dramas, comedias y piezas en un acto traducidas del francés y representadas con general aceptación en los teatros de corte» (BBEE, nº II, I6-6-I850: I69). 
En 1842 Boix lanzó su segunda colección, la Biblioteca de Educación (1842-1845), integrada por 20 títulos en 26 volúmenes entre manuales, historias, compendios, cursos y antologías — «fragmentos»-, algunos recomendadas en colegios y universidades. La intención del editor era «formar una colección de obras de educación por los mejores autores» (ENA, no I15, 23-I-1843: I). Fue inaugurada por Antonio Gil de Zárate con su Manual de literatura (BBEE, III, $\mathrm{n}^{\circ}$ 24, I6-I2-I842: 373), al que siguieron títulos de Alejandro Oliván, Fausto de la Vega, Juan Díaz Baeza, Adolfo Alfredo Camus, Pedro Madrazo, Antonio Rosales, Manuel Benito Aguirre, Francisco Pérez de Anaya, Pedro Higinio Barinaga, Ramón de Navarrete, Antonio Ferrer del Río, José María de Andueza, Venancio Valledor, Fermín Caballero, Joaquín Aguirre, Francisco de Cárdenas, José López Uribe, Nicomedes Pastor Díez, Joaquín Francisco Pacheco, José María Huet, Fernando Álvarez, Vicente Manuel de la Rúa y Manuel Gallardo, P. Ceballos, Tomás García Luna y Jerónimo de la Escosura.

Tras esta colección educativa que salió por suscripción Boix lanzó otras dos de medicina y homeopatía publicadas mediante el mismo sistema de fidelización: la Biblioteca Médica Homeopática (I844-I847), compuesta por las obras de la «nueva escuela médica», y el Tesoro de las Ciencias Médicas (I845-I846), que bajo la dirección - y traducción, en algunos casos- de Francisco Méndez Álvaro ofrecía a médicos, cirujanos, farmacéuticos y estudiantes las obras científicas, manuales y compendios que se estaban publicando en Europa.

La primera tuvo algunas vacilaciones de nombre - Biblioteca Médica Homeopática, Biblioteca de Obras Homeopáticas - y se anunció como «colección de las obras doctrinarias de la nueva escuela médica que son indispensables y al mismo tiempo suficientes para aprender fundamentalmente la homeopatía y practicarla con buen resultado» ( $B B E E$, año VI, no 8, 16-4-1845: II3). Su director fue el profesor de medicina José Sebastián Coll Cochet, pionero de la homeopatía en España, quien poco antes, en I843, había sacado con Lalama el que es considerado el primer estudio homeopático original: el Examen crítico filosófico de las doctrinas médicas homeopáticas y alopática comparadas entre sí. Viendo un posible filón comercial, Boix adoptó esta obra como "prefacio a la colección», que inicialmente prometía en su prospecto 7 títulos en I4 tomos, todos traducidos por el propio Coll - a excepción del Examen-, con títulos como la Exposición de la doctrina médica homeopática de Hahnemann, la Guía del médico homeópata de Ruoff o la Farmacopea homeopática de Jahr ( $L R$, año I, no 24, I6-6-1844: 5-7).

Para el Tesoro de las Ciencias Médicas (1845-I848), por su parte, Boix contó con Francisco Méndez Álvaro, quien se encargó de dirigir a una sociedad de «profesores de medicina» como Mariano Delgrás, Gabriel Usera, Anastasio Chinchilla, Francisco Méndez Álvaro, Francisco Alonso, Serapio Escolar, José Calvo y Martín, Tomás Santero, Rafael Sáez Palacios y Carlos Ferrari, entre otros ( $D B, \mathrm{n}^{\circ}$ 366, 3I-I2-I844: 5296). Su objetivo era «facilitar a los médicos, cirujanos y farmacéuticos las mejores obras de estas ciencias que salen a luz en Europa, manteniéndoles al nivel de los conocimientos de la época, así como proveer a los estudiantes de buenos libros elementales y de manuales o compendios (...) para salir bien de sus exámenes y grados» (BBEE, año VI, no $8, \mathrm{r} 6$ abril I845: II6). Contó con títulos como el Tratado de patología externa y de medicina operatoria de Vidal de Cassis, el Atlas completo de anatomía descriptiva del cuerpo humano de Masse, el Tratado de fisiología de Müller o el tratado original de botánica Introducción al estudio de las plantas de Antonio Blanco Fernández. En 1847, recordemos, el Tesoro contaba con II títulos en 27 tomos, más otros 9 en prensa proyectados en 48 tomos, de los cuales ya se habían impreso i9 (Sociedad, 1847). 
En cuanto a la Colección Económica de las Mejores Novelas Contemporáneas (I846-I847) o «Colección Económica de Novelas Españolas y las Mejores Extranjeras de Autores Acreditados», que conformó a partir de antiguas novelas de su fondo de I830, constaba en 1847 de 8 títulos en 5I tomos (Sociedad, 1847 ), entre los que figuraban Los misterios de París, El judio errante o El Conde de Montecristo.

Otras colecciones proyectadas en Madrid, como una «colección completa de clásicos latinos» que «el señor Boix piensa dar a luz» $\left(C P, \mathrm{n}^{\circ}\right.$ 870, 16-3-1847: 4), no llegaron a realizarse. Sin embargo, Boix continuó explotando este modelo editorial en París, donde impulsó la Biblioteca de las Damas Católicas Españolas y Americanas, una colección de obras de devoción con encuadernaciones populares y de lujo enfocada exclusivamente a un público femenino e hispanoparlante; además, reorganizó hasta donde pudo su antiguo catálogo en una Biblioteca Recreativa Ilustrada, una Biblioteca Científica, una Biblioteca de Religión y una Biblioteca de Educación. Todas se publicitan con sus correspondientes títulos, en un anuncio de su librería y gabinete de lectura. En Valencia, en sus últimos años, lanzó una serie de libros que, sin llegar a constituir una colección como tal, evidencian una línea editorial específica, en concreto, una apuesta por la literatura costumbrista popular de autores valencianos y escrita en valenciano (Peñas, 20I7e). Para estas obras, que salieron entre 1859 y i86o y que abarcaban desde zarzuelas y juguetes de Francisco Palanca y Roca hasta a obras de teatro de José Bernat Baldoví, Boix empleó el nombre de Imprenta de la Rechenerasió Tipográfica.

\subsection{Periódicos y revistas}

Boix lanzó un gran número de periódicos y revistas a lo largo de su carrera. Durante los años 40, su etapa más prolífica también en el ámbito periodístico, triplicó el volumen de títulos que había impulsado en la década anterior: se han podido contabilizar hasta veintiuno, frente a los seis identificados en la etapa anterior.

De entre los que tenían la literatura, la crítica, la sátira y el teatro como pilares centrales hay que señalar forzosamente El Entreacto (I839-I84I), uno de los primeros títulos importantes que lanzó. Editado inicialmente por Juan Díaz de los Ríos, contó con firmas como las de Zorrilla, Hartzenbusch, Martínez Villergas, Ramón de Navarrete, Miguel Agustín Príncipe o Patricio de la Escosura. Le siguió la Revista de Teatros (I84I-I845), que convocó a muchos de los redactores del Entreacto, con información detallada sobre compañías teatrales, carteleras, etc., aunque también con textos de creación. El Laberinto (I843-I845), que tuvo como directores a Antonio Flores y a Antonio Ferrer del Río, se benefició de los adelantos técnicos de las prensas mecánicas de Boix y fue considerada una de las mejores revistas ilustradas del momento ( $L A C H$, año vi, $\mathrm{n}^{\circ}$ 4, 24-4-1862: 16), con «numerosos y excelentes grabados de la mayor actualidad posible» (Opisso, I9I8: 318). De su imprenta de Tarragona destaca El Faro del Francoli (I844-1846), del que era editor y propietario y que Ángel del Arco consideró como «uno de los mejores que ha tenido Tarragona en el campo literario» (1916: 193). En su etapa parisina Boix impulsó un título relevante, El Eco de Ambos Mundos (1852-1855), con el que presentaba competición al Correo de Ultramar, pero que acabó cediendo a los Garnier tras numerosos problemas, además de El Globo Pintoresco (1853); esta publicación quincenal, asociada al Eco, se planteó «para los amantes de la literatura» y pretendía cubrir el hueco de dos revistas similares que salían en París en español y que habían desaparecido por aquel entonces ( $L E, \mathrm{n}^{\mathrm{o}}$ I542, IO-4-1853: 4). De sus últimos años como editor e impresor en Valencia destacan dos periódicos literarios, La Guirnalda (1856-1857), dirigido por Juan Ortiz Máiquez, y El Eco 
del Turia (1857-1858), con redactores como Vicente Boix, Rafael Blasco, Teodoro Llorente o Rafael Ferrer y Bigné (Tramoyeres, 1880: 89).

En cuanto a sus periódicos de información y política, hay que consignar su publicación liberal El Progreso (1838-1839) y su Revista del Progreso (I84I), de muy corta vida, pero que tuvo entre sus directores a Jacinto de Salas y Quiroga y a Cayetano Cortés (Hartzenbusch e Hiriart, 1893: 57, 72). Boix también fue editor responsable del periódico progresista Eco del Comercio durante unos meses de i838, así como editor propietario de ElTiempo: Diario Conservador (I844-I847), en cuyo seno empezó a salir los lunes El Laberinto como «revista pintoresca», con Manuel Moreno López de director (Hartzenbusch e Hiriart, 1893: 95) y que usó, como era habitual, como tribuna bibliográfica y publicitaria de su propio catálogo. De su etapa final destaca El Eco de Valencia (1859), dirigido por Eduardo Inza, activo solo desde abril hasta junio de 1859 y que aparecía en la cuarta página de La Correspondencia de España.

Finalmente, Boix asumió la publicación de órganos periodísticos de instituciones como el Boletín Oficial de la Milicia Nacional del Reino (I838-I839) o la Real Sociedad Económica Matritense (El Amigo del País, 1844-1849), además de otros títulos especializados como la Gaceta de los Tribunales (184I), la Revista cientifica e industrial(1845) y el Diario de Avisos de Madrid (184I-I847).

\section{EPÍlogo}

Ignacio Boix apostó por las colecciones literarias y dramáticas y cuidó a toda clase de público con formatos, encuadernaciones y temáticas diversos, ganó subastas para la impresión de periódicos oficiales, elevó solicitudes y propuestas al Congreso, se sumó en París a la creación de proyectos editoriales centrados en el mercado americano, se preocupó por introducir los avances técnicos del extranjero en tipografía e ilustración, dio espacio en sus periódicos y ediciones a los escritores y traductores más notables del momento y llegó contar con una plantilla considerable. Su espíritu emprendedor le valió el calificativo popular de "editor infatigable», esgrimido con admiración por unos y con sorna por otros. Antonio Flores, director de su Laberinto, dijo de él que era «de suyo activo» y que «la prensa periódica le llama infatigable» ( $E L, \mathrm{I}, \mathrm{n}^{\circ} \mathrm{IO}, \mathrm{I} 6-3^{-1844}$ : 138 ); otros hablaban de «la infatigable laboriosidad del señor Boix» $\left(R T, 2^{\mathrm{a}}\right.$ serie, $\mathrm{n}^{\circ} 47, \mathrm{I} 4-2-1843$, s. p.) o de «las prensas infatigables del señor Boix» ( $B E$, año I, tomo I, $\mathrm{n}^{\circ}$ 7, I5-4-1845: 99). Asimismo, se destacó su «don de la oportunidad» $\left(C P, \mathrm{n}^{\circ}\right.$ 23I 6 , 2I-I-I85I: 2-3) y ese «genio, emprendedor y activo y audaz como pocos» que lo llevó a acometer diferentes empresas ( $L I$, año IX, I7-4-I862, no 2272: 3). En opinión de Julio Nombela, Boix y Mellado fueron «los editores que de más boga gozaban en aquel tiempo» (I909: 95).

La constancia de Boix contribuyó al éxito de sus negocios en los años 40, aunque también fue fundamental el soporte financiero que recibió de Fagoaga. En un momento en el que las prácticas habituales para adquirir capital solían ser la autofinanciación mediante beneficios y las suscripciones, más que el sometimiento al «prestamista con rasgos de usura» (Martínez Martín, 2009: 47), Boix apostó fuerte en ese sentido. Su ambición profesional, plasmada en la multitud de proyectos que emprendió e ideó, lo llevó a endeudarse notablemente y a buscar nuevas salidas empresariales, en Francia primero y en Valencia después, aunque nunca llegó a recuperarse del revés que sufrió a finales de los 40.

En «un contexto de progresiva pérdida del valor social de las jerarquías tradicionales y del surgimiento de una sociedad basada en la meritocracia» (Sánchez, 2or7: 19), su origen humilde no impidió a Boix integrarse en el entramado de la élite burguesa isabelina, recurriendo para ello a prácticas habituales en el sector editorial, así como a 
otras no tan comunes. Si «la cautela fue la estrategia común, poco proclive a la expansión o diversificación fuera del sector $\mathrm{y}$, en todo caso, de forma muy controlada» porque el patrimonio familiar «estaba comprometido con unas empresas sostenidas ilimitadamente por la responsabilidad de sus propietarios» (Martínez Martín, 2009: 46), Boix rompió con esta pauta al asumir notables riesgos en sus actividades, lo que, de hecho, terminó por arruinarle. Sí se sometió a la política de influencias y, para ello, apeló a las Cortes para impulsar proyectos como el relativo a la introducción de clichés extranjeros en España, que el diputado Álvaro Gil Sanz presentó en su nombre ante el Congreso de los Diputa$\operatorname{dos}\left(D S C, \mathrm{n}^{\circ} 92, \mathrm{I}\right.$ 8-4-1842: 2502) y que le supuso un enfrentamiento con artistas, pintores y grabadores españoles; también recurrió a sus productos como plataforma adulatoria, como se aprecia en la dedicatoria del Panléxico a Fagoaga, estampada al poco de empezar a recibir sus préstamos, o en el lujoso Devocionario regio que imprimió para uso de Isabel II, o en la dedicatoria a Espartero en otra de sus obras, a quien poco después, el 3 de junio de 1842, solicitó la cruz de caballero de la Orden de Carlos III (AHN, Estado, leg. 6289, 6).

E1 Duque de la Victoria, de hecho, concedió a Boix por decreto la cruz supernumeraria, libre de gastos, días más tarde, el 7 de junio de I842, en atención a sus servicios «a favor de la causa de la libertad, así en la presente época como en la anterior del año 20 al 23", así como por haber impreso a su costa la Novísima recopilación de leyes de Indias. Sin embargo, Boix no obtuvo definitivamente la cruz hasta cinco años más tarde, cuando se suprimió el requisito de aportar pruebas genealógico-nobiliarias, algo que Boix, dados sus orígenes humildes, no podía presentar; así, eximido ya de tal requisito, se le expidió en Palacio el título de caballero el I4 de agosto de $1847^{52}$. La historia de la distinción de la Cruz de Carlos III concedida a Boix se puede reconstruir gracias al conjunto de documentos que atesora el Archivo Histórico Nacional (AHN, Estado, leg. 6289, 6; leg. 7373, 8 ; leg. $\left.7379^{\mathrm{I}}, 54\right)$.

No fue esta la única distinción que recibió. También fue Impresor de Cámara de Su Majestad, según él mismo estampó en un catálogo de I858 (en Serrano, I898-I899: 24) e Impresor del Ayuntamiento de Valencia, cargo que recogía en el pie de imprenta de algunas de sus últimas obras, a lo que se suman los reconocimientos que le dispensó la Sociedad Económica Matritense por sus adelantos industriales y tipográficos. Tampoco quedó al margen de las principales instituciones de sociabilidad: fue socio de la Sociedad Filantrópica de Milicianos Nacionales Veteranos de Madrid (Sociedad Filantrópica de Milicianos, I840: 13), del Liceo en I841, de la Sociedad Económica Matritense en I842 (SEM, Expediente de admisión de socio, leg. 365/4) y de la Sociedad Sevillana de Emulación y Fomento, de la que fue fundador, según la esquela fúnebre de Boix que reprodujo Serrano y Morales (1898-1899: 25). En suma, tuvo una intensa participación en la vida cultural madrileña de los años 40 y no quedó tampoco ajeno a la vida política; además de la significación liberal que evidenciaban sus publicaciones, se implicó activamente y se presentó a las elecciones municipales a la Alcaldía Constitucional de Madrid en 1844, en las que quedó como suplente de regidor ( $E C, \mathrm{n}^{\circ}$ 53I, 28-5-I844: 4; $D M, \mathrm{n}^{\mathrm{o}} 2 \mathrm{II}, 29^{-5}-\mathrm{I} 844$, s.p.).

52 Martínez Martín (2018: 363 ) apunta que Boix recibió la Cruz en agosto de 1847 —es decir, seis meses después de que le fuera otorgada a Mellado (364) - , pero no que la concesión original data en realidad de 1842 , pues solamente maneja el último de los documentos arriba citados (AHN, Estado, 7379, 54). En cuanto a otros premios u honores, la nota manuscrita en el retrato de Boix (Anónimo: 1849) señala que también obtuvo la Cruz de Isabel la Católica, aunque no he encontrado constancia de ello, más bien al contrario. El editor la solicitó el 20 de marzo de 1843, en efecto, a lo que la Subsecretaría respondió: «Boix ha sido ya recompensado al paso que otros y beneméritos funcionarios públicos no han obtenido la menor distinción» (AHN, Consejos, II315, I20). No hay pruebas documentales posteriores de la concesión. 
Ignacio Boix murió en Valencia el II de abril de I862. Tenía 55 años. En la necrológica que circuló por los principales periódicos se resaltó su impulso «al renacimiento literario» en España gracias a sus obras «numerosas e importantísimas», pero también se destacó su caída en desgracia: tras «haber manejado cuantiosos capitales acaba de morir pobre y casi olvidado en Valencia» ( $L C E$, año XV, no I.397, I2-04-1862: 3), «después de una penosa enfermedad» ( $D B, \mathrm{n}^{\circ}$ I04, I4-4-1862: 3310). Otras notas resaltaron igualmente el triste final del «antiguo impresor, y uno de los editores que más servicios ha prestado en España a las letras» ( $D B, \mathrm{n}^{\circ}$ I04, I4-4-1862: 3310). Por su parte, Roberto Robert quiso recordarle «por su actividad y buenos deseos en las empresas editoriales», pero también llamó la atención sobre que «España le debía la propagación de algunos buenos originales, como El Diablo Mundo, Los españoles pintados por sí mismos y otros» (La Discusión, año vir, no 1937,15-4-1862: 3).

En este conjunto de recuerdos destacan unas líneas de su antiguo colaborador Ferrer del Río, quien evocó al «hombre emprendedor y activo» que «figuró entre los que dieron mayor impulso a la imprenta y a la literatura»; por ello se lamentaba, tras revisar sus principales publicaciones: «De sentir es que haya muerto pobre quien tanto puso de su parte por difundir las luces en su patria» ( $L A C H$, año vI, $\mathrm{n}^{\circ}$ 4, 24-4-1862: I6). Una necrológica que se presenta a modo de semblanza biográfica sobresale, sin embargo, por su tono íntimo y por la riqueza de datos que ofrece, lo que hace pensar en la relación de cercanía de su anónimo autor o autora con el editor: ${ }^{53}$

El editor Boix. Acaba de morir en Valencia el célebre y bien conocido editor don Ignacio Boix, y ha muerto pobre y arrinconado después de haber sido uno de los hombres a quienes debe más la imprenta española y que más contribuyó en sus buenos días a dar impulso a nuestra literatura, propagando algunas de las obras más importantes de nuestros mejores ingenios. Desde 1840 a I 847 fue su establecimiento tipográfico en progreso siempre creciente, desmoronándose, por desgracia, cuando tuvo lugar la crisis monetaria que tantas otras casas hundió y con tantas fortunas dio al traste. Durante ese espacio de tiempo, acometió distintas empresas en alas de su genio, emprendedor y activo y audaz como pocos, dando a luz una gran porción de obras de diferentes autores, entre las cuales figuran publicaciones tan importantes como las Leyes de Indias; el magnífico Devocionario regio, cuyas láminas sirvieron más adelante para exornar la segunda edición del Devocionario poético del señor Príncipe; el Panléxico de Peñalver, Diccionario de la Lengua y de Sinónimos, de la Fábula y de la Rima; el Febrero novísimo, por los señores Goyena y Aguirre; las Escenas matritenses, del señor Mesonero Romanos; Los Españoles pintados por si mismos, notabilísima colección de artículos de costumbres debidos a nuestras primeros autores; el Diccionario de agricultura, de Rocier (sic); las Alegaciones fiscales, de Campomanes; los Viajes cientificos alrededor del mundo, por Michelena; la Galería de hombres célebres contemporáneos, por los señores Cárdenas y Pastor Díaz; 24 obras de medicina, algunas de ellas en $\mathrm{I} 3$ tomos, y más de 200 titulos de comedias.

También publicó, entre otras notables poesías, los Cantos del Trovador, de Zorrilla.

Esta breve indicación es bastante para dar una idea del vastísimo y ancho campo que Boix dio a sus publicaciones, sosteniendo en su establecimiento una multitud de familias, y pagando como editor las obras originales a un precio a que antes de satisfacerlo él no estaban acostumbrados nuestros autores, a los cuales dio constan-

53 También constituye una llamada de socorro a su viuda e hijo, como se desprende de las palabras finales. 
temente muestras vivísimas de interés, consideración y desprendimiento. Su justa nombradía como tal editor, y como impulsador en tal concepto de nuestra moderna literatura, le valieron el ser condecorado con la cruz de Carlos III, y con el título de secretario honorario de S. M., conquistándole las simpatías y el afecto de nuestros primeros literatos, los cuales recordarán siempre su nombre con el aprecio a que es acreedor. Su desgracia, cuando la crisis comercial, le obligó a trasladarse a París, donde su genio estuvo casi a punto de hacerle reconstruir la gran fortuna que había perdido: pero venció al fin la mala estrella que había comenzado a perseguirle, y volviendo a España intentó los medios de levantarse por tercera vez en la provincia donde ha fallecido.

Allí consiguió plantear un notable establecimiento, y allí reimprimió la gran obra de nuestras Leyes de Indias, base acaso de su fortuna anterior; pero los tiempos eran ya otros, y ni esa ni otras obras notables en que invirtió todos sus recursos, compensaron los muchos gastos a que habían dado lugar, ni menos los de imprenta y fundición que en gran escala había montado. Tantos contratiempos, unidos al recuerdo de tiempos mejores, convirtieron en taciturno y sombrío al hombre que antes era tan decidor, tan jovial y tan expansivo, y minando su salud poco a poco, acabaron por abrirle el sepulcro al que acaba de descender. Deja una viuda sin recurso alguno, y un hijo privado de todo amparo; pero llevan el nombre de Boix, y ese nombre deberá servirles de algo para que contribuyan a hacer menos desgraciada su suerte los que en los buenos tiempos de ese pobre editor, hoy difunto, le debieron ya protección, ya recursos, ya consideraciones o respetos, que nunca podrán olvidar (LI, año IX, nº 2272, I7-4-I862: 3).

Estos recuerdos anónimos siguen los pasos de Boix en Madrid, París y Francia, a la par que evocan algunos de sus mayores éxitos y sonados fracasos, pero, sobre todo, suponen una llamada de atención sobre su aportación a la literatura y a la edición españolas, así como un intento de restituir el nombre de Boix y mitificarlo en un momento en que todas las necrológicas dedicaban unas escuetas líneas al malogrado editor, olvidado ya por todos.

Hoy Ignacio Boix sigue en el olvido. El presente trabajo aspira a sacarlo de él, ofreciendo un primer acercamiento a su figura y dando a conocer su valor y alcance; ahora bien, aún quedan muchos puntos oscuros por aclarar, desde qué pasos dio en sus primeros años hasta cómo accedió al mundo del libro, cuál fue su participación exacta en la Milicia o las implicaciones de sus contactos y actividades políticas, entre otros. Volviendo a la idea inicial con la que se abría este trabajo, la trayectoria de Boix, aquí apenas esbozada, merece ser analizada en profundidad en un libro que permita arrojar verdadera luz sobre la biografía, las prácticas editoriales y el tejido empresarial de uno de los grandes nombres propios de la edición española del segundo tercio del siglo xIX.

\section{BiBLIOGRAFÍA}

Alonso Cortés, Narciso (1917), Zorrilla. Su vida y sus obras, Valladolid, Excmo. Ayuntamiento, vol. I.

Anónimo (1863), El consultor: nueva guía de Barcelona. Libro de grande utilidad para los vecinos y forasteros, y sumamente indispensable a todos los que pertenecen a las clases mercantil e industrial, por J. A. S. y M. Ll., Barcelona, Establecimiento Tipográfico de Narciso Ramírez. 
Anónimo (I849), [Retrato de Ignacio Boix y Blay, con semblanza biográfica manuscrita al pie], Madrid, P. Rodríguez, Litografía de J. Aragón, en Universidad de Navarra, Depósito Académico Digital, https://goo.g1/YMZxD9

Anónimo (1848), Diccionario de legislación penal con arreglo al código sancionado por S.M. en I9 de marzo de 1848, publicación dirigida por D. V. F. y F., Valencia, Valencia, Librería de Casiano Mariana (...) y en la de Antonio Matton.

— (1843), Diario de los sucesos de Barcelona en setiembre, octubre y noviembre de 1843, con un apéndice que contiene los documentos oficiales más importantes, por unos testigos presenciales, Barcelona, Imprenta y Librería de Pablo Riera.

- (I84I), «Decreto de la Regencia autorizando a Boix para que reimprima y expenda por su cuenta la Recopilación de las Leyes de Indias», Ministerio de Gracia y Justicia, en Colección de las leyes, decretos y declaraciones de las Cortes, y de los Reales Decretos, órdenes, resoluciones y reglamentos generales expedidos por las Secretarias de Despacho desde $I^{\circ}$ de enero hasta fin de diciembre de I840, vol. 26, Madrid, Imprenta Nacional, pp. 488-489.

Arco y Molinero, Ángel del (1916), La imprenta en Tarragona. Apuntes para su historia y bibliografía, Tarragona, Imprenta de José Pijoán.

Borx, Ignacio (1854), «Advertencia del editor», en Pedro Martínez López, Novísimo diccionario de la lengua castellana (...), París, A. Lefèvre, Librero, Señores Ignacio Boix y Cía, Editores, Calle de Richelieu, núm. 2, Gran Círculo Español y Americano, s.p.

- (I845), Muestras de los caracteres modernos de la fundición de Ignacio Boix, dirigida por Mr. Demailly y D. Ramón Alvarez: primer cuaderno, Madrid, Imprenta, Estereotipia, Fundición, Grabado y Litografía de Boix, Editor, I845.

- (I842), «Obras del fondo y surtido de Don Ignacio Boix», en Alfredo Adolfo Camus, Compendio elemental de historia universal, vol. I, Madrid, Boix, Editor, Imprenta y Librería, Calle de Carretas, no 8, pp. 317-320.

- (1840), «Obras de fondo propias de D. Ignacio Boix», en Anónimo, Manual completo del albañil-yesero, del solador y del pizarrero, añadido con un prontuario de las voces técnicas principales usadas en estas artes, asi como en la arquitectura, necesarias a todo buen albañil, Madrid, Boix, Editor, Impresor y Librero, Calle Carretas, pp. I49-159.

- (1833), Caracteres, emblemas y adornos de que está surtida la imprenta de D. Ignacio Boix, sita Carrera de San Jerónimo, $n^{\circ}$ Io, antes de llegar a la lotería de las Cuatro Calles. Junio I833, Madrid, Imprenta de Ignacio Boix.

Boix y CíA. (1846), Catálogo de las obras que se hallan en venta en la librería de Boix y compañía a cargo de Antonio Matton y Curtoys y de su hijo Eduardo, Caracas, Imprenta de Valentín Espinal.

Botrel, Jean-François (I997), «L'Espagne et les modèles éditoriaux français (I830-I850)», en J.-R. Aymes y J. Fernández Sebastián (eds.), L’image de la France en Espagne (1808-1850). Colloque international de Paris III-Sorbonne Nouvelle CRODEC (Centre de Recherche sur les Origines de l'Espagne Contemporaine) Paris, I-2 décembre 1995, París, Presses de la Sorbonne Nouvelle, pp. $227^{-242 .}$

Bottin, Sébastien (I855), Almanach-Bottin du commerce de Paris, des départements de la France et des principales villes du monde (...), París, Bureau de l'Almanach du Commerce, I855.

Caballé Masforroll, Anna (I998), «Memorias y autobiografías en la literatura española del siglo XIX», en Víctor García de la Concha (dir.), Leonardo Romero Tobar (coord.), Historia de la literatura española. Siglo XIX (II), Madrid, Espasa, pp. 347-364.

Compañía General del Iris (I844), Estatutos de la Compañia General del Iris, Madrid, Imprenta de D. Ignacio Boix.

Cotarelo y Mori, Emilio (I928), «Editores y galerías de obras dramáticas en Madrid en el siglo XIX», Revista de la biblioteca, archivo y museo, año V, abril, $n^{\circ}$ I8, pp. I2I-I39. 
Fernández Rodríguez, Pura (I998), «El monopolio del mercado internacional de impresos en castellano en el siglo xIx: Francia, España y "la ruta" de Hispanoamérica», Bulletin Hispanique, I0о-I, pp. I65-190.

Gifra Adroher, Pere (2006), «Ramón de Valladares, traductor y adaptador de Oncle's Tom Cabin», en Francisco Lafarga y Luis Pegenaute (eds.), Traducción y traductores, del romanticismo al realismo, Bern, Peter Lang, pp. 217-230.

Guía de forasteros en Madrid para el año de I848, Madrid, Imprenta Nacional.

Gutiérrez-Poch, Miquel (2016), Tradición, conocimiento y modernidad. Las claves del éxito de Miquel y Costas E Miquel, S. A. Siglos XVIII y XIX, Barcelona, Universitat de Barcelona.

GüEll Junkert, Manel (20I4), «Boix Blay, Andreu», en Manel Guëll y Salvador-Joan Rovira i Gómez (coords.), Biografies de Tarragona, vol. 4, Benicarló, Onada Edicions, p. 34.

Hartzenbusch, Juan Eugenio (s. a.), «Cuentes el día de hoy cien y cien veces,/ vertiendo el Cielo en ti pródigos dones», Papeles de Juan Eugenio Hartzenbusch, Biblioteca Nacional de España, MSS/20834/52.

Hartzenbusch e Hiriart, Eugenio (igoo). Bibliografia de Hartzenbusch (Excmo. Sr. D. Juan Eugenio), Madrid, Establecimiento Tipográfico «Sucesores de Rivadeneyra».

- (I894), Apuntes para un catálogo de periódicos madrileños desde el año I66I al I870, Madrid, Establecimiento Tipográfico de los Sucesores de Rivadeneyra.

Hortelano, Benito (1936), Memorias de Benito Hortelano, Madrid, Espasa-Calpe.

Llanas, Manuel (2004), L'edició a Cataluña: el segle XIX, Barcelona, Gremi d'Editors de Catalunya, Colección Història de la edició a Catalunya.

López Zazo, Ruth (2010), La actividad editorial de Francisco de Paula Mellado, Trabajo Fin de Máster, Máster en Gestión de la Documentación y Bibliotecas, Facultad de Ciencias de la Documentación, Universidad Complutense de Madrid, https://goo.gl/j48eDB

Martínez Martín, Jesús Antonio (2018), Los negocios y las letras. El editor Francisco de Paula Mellado (1807-1876), Zaragoza, Prensas de la Universidad de Zaragoza.

- (2009), Vivir de la pluma. La profesionalización del escritor, 1836-1936, Madrid, Marcial Pons.

Matton, Antonio y Boix, Ignacio (I83I), «Libros de fondo y surtido de los señores Matton y Boix, que se hallarán en pasta en la misma librería, carrera de S. Jerónimo, no 10 , junto a la administración de loterías de las cuatro calles», en P. A. García Gil y Bueno, Adivinanzas, o sea, colección de charadas y enigmas o juego de discurrir, completo y reducido a pequeños conceptos por..., Madrid, Imprenta, Librería, Almacén de Papel y Estampado de Jordán, pp. 51-64.

- (I830), «En la misma librería se hallarán las siguientes a precios cómodos», en Stéfanie-

Félicité Du Crest Genlis, Valeria y Beaumanoir, ola caprichosa penitencia, por Madama Genlis; traducida del francés por Manuel Marqués, Madrid, Imprenta de Burgos, Librería de Matton y Boix, pp. I45-I52.

Ménguez Rodríguez, Felipe (2007), «Las dos caras de Jano: notas sobre las memorias de Benito Hortelano y Mariano de Cabrerizo», en Antonio Castillo Gómez (dir.) y Verónica Sierra Blas, (eds.), El legado de Mnemosyne. Las escrituras del yo a través del tiempo, Gijón, Ediciones Trea, Biblioteconomía y Administración Cultural, I72, pp. 259-27I.

Mesonero Romanos, Ramón de (1842), Escenas matritenses, por el Curioso Parlante. Tercera edición, corregida y aumentada por el autor, y adornada con láminas, I, Madrid, Yenes.

Moreno Fernández, Rafael (2010), El personal del Banco de España: desde su origen en el siglo XVIII hasta fin del siglo XIX. Vol. 2: Banco de San Fernando (I829-I856), en Estudios de Historia Económica, 5, Madrid, Banco de España.

Nombela Tabares, Julio (I909), Impresiones y recuerdos. Tomo primero: de I836 a I850, Madrid, Casa editorial de «La última moda».

Opisso, Alfredo (1908), Semblanzas políticas del siglo XIX, Barcelona, Herederos de Juan Gili. 
Orinuela, Andrés Avelino de ([1852-I854]), «[Cartas], I852-1854, París y Londres, a Juan Eugenio Hartzenbusch», Papeles de Juan Eugenio Hartzenbusch, Biblioteca Nacional de España, $\mathrm{MSS} / 20808 / 98$.

Otazu y Llana, Alfonso de (1970), Hacendistas navarros en Indias, Bilbao, Gráficas Ellacuria.

Peñas Ruiz, Ana (20I7a), «Semblanza de Ignacio Boix y Blay (I807-1862)», en Biblioteca Virtual Miguel de Cervantes-Portal Editores y Editoriales Iberoamericanos (siglos XIX-XXI)EDI-RED, https://goo.gl/mkJrG 4

- (20I7b), «Semblanza de la Casa de Matton y Boix (I830-I833)», en Biblioteca Virtual Miguel de Cervantes-Portal Editores y Editoriales Iberoamericanos (siglos XIX-XXI)EDI-RED, https://goo.g1/SGXous

- (20I7c), «Semblanza de la Casa de Ignacio Boix (I838-I862)». En Biblioteca Virtual Miguel de Cervantes-Portal Editores y Editoriales Iberoamericanos (siglos XIX-XXI)EDI-RED, https://goo.g1/MC79mG

- (20I7d), «Semblanza de la Imprenta de la Regeneración Tipográfica de Ignacio Boix (1856-1862)», en Biblioteca Virtual Miguel de Cervantes-Portal Editores y Editoriales Iberoamericanos (siglos XIX-XxI)-EDI-RED, https://goo.g1/Lj7gjj

- (20I7e), «Semblanza de la Imprenta de la Rechenerasió Tipográfica de Ignacio Boix (I859-1860)», en Biblioteca Virtual Miguel de Cervantes-Portal Editores y Editoriales Iberoamericanos (siglos XIX-XXI)-EDI-RED, https://goo.gl/y8aZJp

- (20I7f), «Semblanza de Andrés Boix y Blay (I830-I858)», en Biblioteca Virtual Miguel de Cervantes-Portal Editores y Editoriales Iberoamericanos (siglos XIX-XXI)-EDI-RED, https://goo.gl/FPVVmp

- (20I4), «Los españoles pintados por sí mismos (I843-I844)», en El artículo de costumbres en España (I830-I850), Vigo, Academia del Hispanismo, pp. 202-216.

Planimetría general de Madrid. Asientos (1988), Madrid, Ediciones Tabapress.

Rey Sayagués, Andrés del y Fernández Lera, Rosa (I999), «Epistolario de Leopoldo Augusto de Cueto, marqués de Valmar, en la Biblioteca de Menéndez Pelayo», Boletín de la Biblioteca de Menéndez Pelayo, año Lxxv, enero-diciembre, pp. 403-505.

Rodríguez-Moñino, Antonio (I945), Catálogos de libreros españoles (I66I-I840). Intento bibliográfico, Madrid, Talleres de Langa y Compañía.

SAlvá, Vicente (I846), Nuevo diccionario de la lengua castellana (...), 2 a ed., París, Salvá.

SÁnchez GArcía, Raquel (20I7), Mediación y transferencias culturales en la España de Isabel II. Eugenio de Ochoa y las letras europeas, Madrid, Iberoamericana Vervuert.

Sanchiz Ruiz, J. y Gayol, V. (s. a.), «Andrés Boix Blay», Seminario de Genealogía Mexicana, en Geneanet, https://goo.gl/ugcYj9

SAurí, Manuel y Matas, José (I842), Guía de forasteros en Barcelona, judicial, gubernativa, administrativa, comercial, artística y fabril (...). Arreglada y coordinada por D. M. S. y D.J. M., Barcelona, Imprenta y Librería de D. Manuel Saurí.

Sirey, Jean-Baptiste (I863), «Propieté Littéraire, Étranger Contrefaçon, Clichage, Prescription», en Recueil général des lois et des arrêts, en matière civile, criminelle, commerciale et de droit public (...). $2^{a}$ serie - 1863 , vol. 42, París, Bureaux de l'Administration du Recueil, pp. 36-38.

Sociedad Filantrópica de Milicianos Nacionales Veteranos de Madrid (i840), Reglamento de la Sociedad Filantrópica de Milicianos Nacionales Veteranos de Madrid, Madrid, Imprenta de don León Amarita.

Sociedad Tipográfico-Literaria Universal La Ilustración (i847), Catálogo general de los libros de fondo de la Sociedad de la Ilustración: calle de Carretas, número 27, Madrid, Sociedad Tipográfico-Literaria Universal La Ilustración. 
Serrano y Morales, José Enrique (I898-1899), Reseña bistórica en forma de diccionario de las imprentas que han existido en Valencia desde la introducción del arte tipográfico en España hasta el año I868 con noticias bio-bibliográficas de los principales impresores, Valencia, Imprenta de F. Domènech.

Tramoyeres Blasco, Luis (I880), Periódicos de Valencia. Apuntes para formar una biblioteca de los publicados desde 1526 hasta nuestros días, Valencia, Imprenta de Domènech.

Ucelay da Cal, Margarita (I951), Los españoles pintados por sí mismos, I843-1844. Estudio de un género costumbrista, México, El Colegio de México.

Zorrilla y Moral, José (i88o), Recuerdos del tiempo viejo, vol. I, Barcelona, Imprenta de los Sucesores de Ramírez y Cía.

- (I882a), Recuerdos del tiempo viejo, vol. II, Madrid, Tipografía Gutenberg.

- (I882b), Hojas traspapeladas de los recuerdos del tiempo viejo, vol. III, Madrid, Tipografía

Gutenberg.

Archivos

AGA (Archivo General de la Administración)

AHAT (Arxiu Històric Arxidiocesà de Tarragona)

AHICAM (Archivo Histórico del Ilustre Colegio de Abogados de Madrid)

AHN (Archivo Histórico Nacional)

AHPM (Archivo Histórico de Protocolos de Madrid)

AVM (Archivo de la Villa)

BNE (Biblioteca Nacional de España)

RMM (Registro Mercantil de Madrid)

SEM (Real Sociedad Económica Matritense de Amigos del País)

Periódicos y revistas

AP (El Amigo del Pais. Periódico de la Sociedad Económica Matritense, Madrid)

$B E$ (Bibliografía de España, Madrid)

$B B E E$ (Boletín Bibliográfico Español y Extranjero, Madrid)

CdP (Centinela de la Patria, Caracas)

CP (El Clamor Público, Madrid)

$D A M$ (Diario de Avisos de Madrid)

DB (Diario de Barcelona)

$D M$ (Diario de Madrid)

DSC (Diario de las Sesiones de Cortes, Madrid)

EC (Eco del Comercio, Madrid)

ECPLM (El Correo. Periódico Literario y Mercantil, Madrid)

EE (El Entreacto, Madrid)

EL (El Laberinto. Periódico Universal, Madrid)

ENA (El Nuevo Avisador, Madrid)

ET (El Tiempo. Diario Conservador, Madrid)

FJL (Feuilleton du Journal de la Librairie, París)

GM (Gaceta de Madrid)

JDPL (Journal des Débats Politiques et Littéraires, París)

LCA (La Correspondencia Autógrafa, Madrid) 


\author{
LEp (La Época, Madrid) \\ $L E$ (La España, Madrid) \\ LI (La Iberia. Diario liberal, Madrid) \\ LN (La Nación. Periódico Progresista Constitucional, Madrid) \\ LP (La Posdata, Madrid) \\ LR (La Luz Riojana. Periódico Literario y de Anuncios, Logroño) \\ LS (La Sociedad. Periódico Político y Literario, México) \\ MM (El Moro Muza, Madrid) \\ $R V$ (Revista de Teatros, Madrid)
}

